In cooperation with the Department of the Navy, Southern Division Naval Facilities Engineering Command

\title{
Computer-Model Analysis of Ground-Water Flow and Simulated Effects of Contaminant Remediation at Naval Weapons Industrial Reserve Plant, Dallas, Texas
}

Water-Resources Investigations Report 00-4197

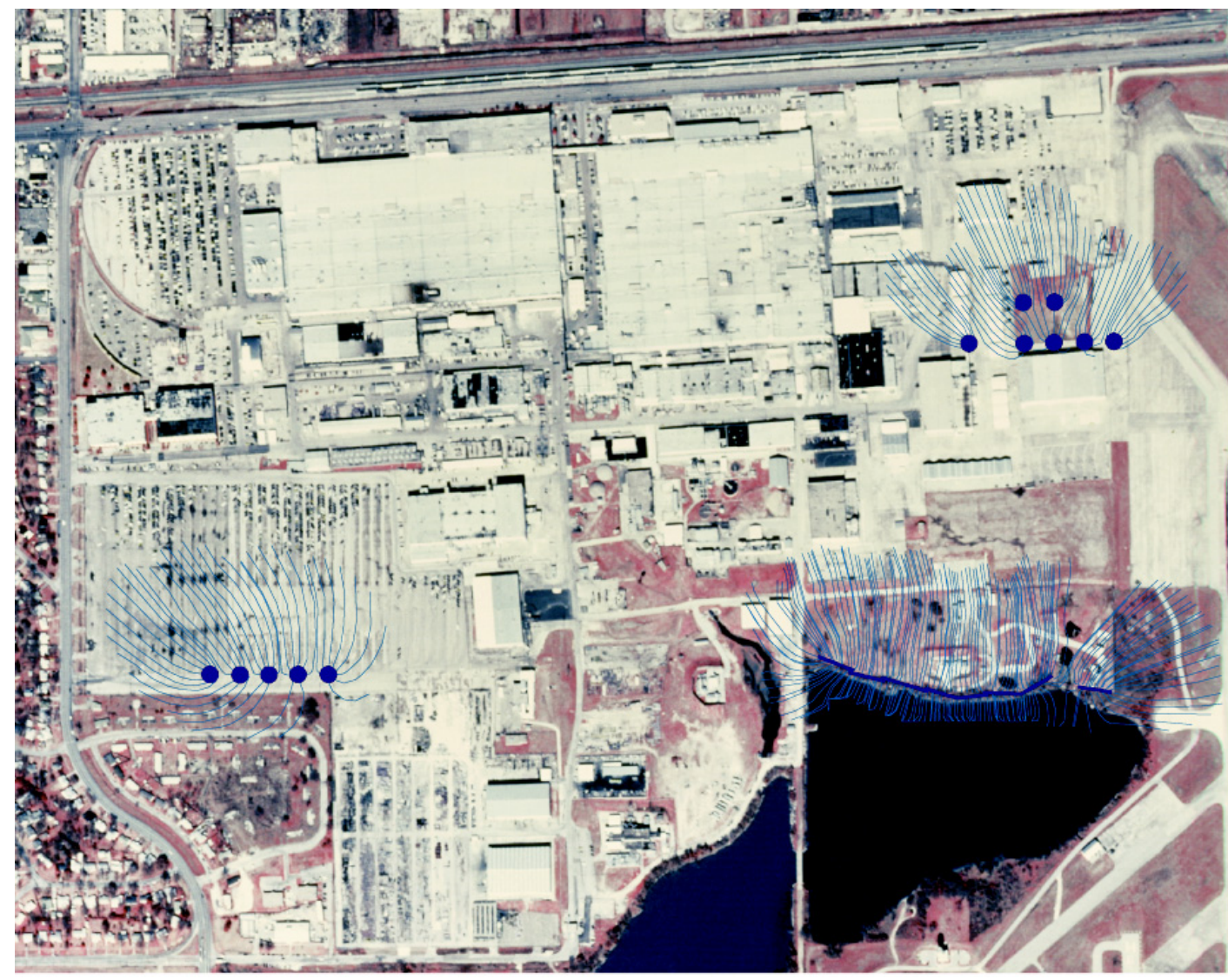

U.S. Department of the Interior U.S. Geological Survey 
U.S. Department of the Interior

U.S. Geological Survey

\section{Computer-Model Analysis of Ground-Water Flow and Simulated Effects of Contaminant Remediation at Naval Weapons Industrial Reserve Plant, Dallas, Texas}

By René A. Barker and Christopher L. Braun

\section{U.S. GEOLOGICAL SURVEY}

Water-Resources Investigations Report 00-4197

In cooperation with the Department of the Navy, Southern Division Naval Facilities Engineering Command 


\section{U.S. DEPARTMENT OF THE INTERIOR}

Bruce Babbitt, Secretary

\section{U.S. GEOLOGICAL SURVEY}

Charles G. Groat, Director

Any use of trade, product, or firm names is for descriptive purposes only and does not imply endorsement by the U.S. Government.

For additional information write to

\section{District Chief}

U.S. Geological Survey

8027 Exchange Dr.

Austin, TX 78754-4733

E-mail: dc_tx@usgs.gov

Copies of this report can be purchased from

U.S. Geological Survey

Branch of Information Services

Box 25286

Denver, CO 80225-0286

E-mail: infoservices@usgs.gov 


\section{CONTENTS}

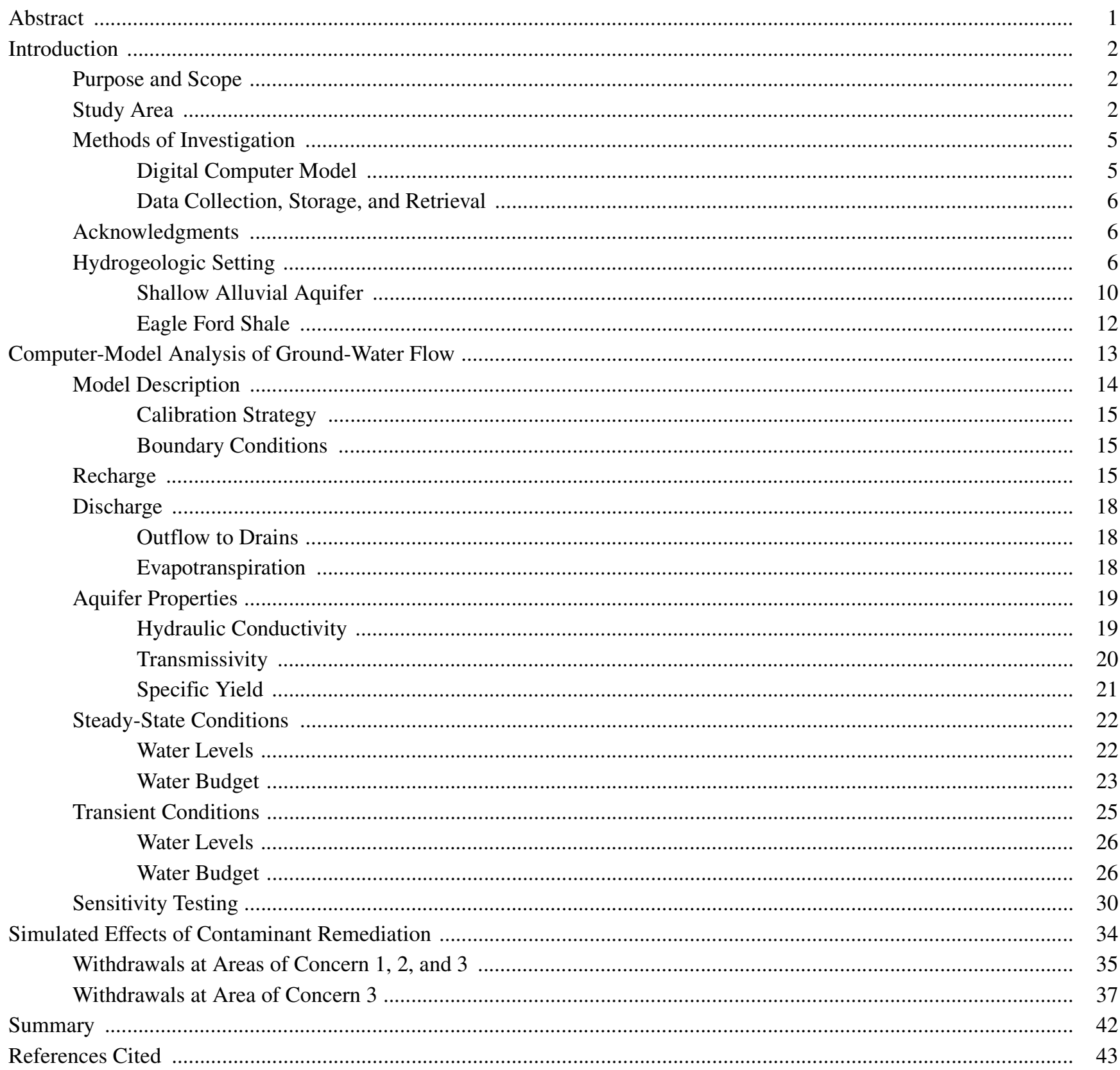

\section{PLATES}

(Plates are in pocket)

1. Hydrographs showing water levels measured in selected observation wells in the shallow alluvial aquifer underlying the study area, 1993-98

2. Hydrographs showing simulated rates of recharge to (in) and discharge from (out) the shallow alluvial aquifer underlying the study area, without and with remediation wells and recovery trench, 1992-98 


\section{FIGURES}

1-3. Maps showing:

1. Location of study area

2. Locations of Naval Weapons Industrial Reserve Plant, Naval Air Station, and off-site water bodies ....... 4

3. Locations of model area, roads, railroads, runways, on-site water bodies, and buildings associated with Naval Weapons Industrial Reserve Plant and Naval Air Station

4. Diagrammatic section showing conceptualized hydrogeologic setting and estimated long-term average rates of ground-water recharge (inflow) and discharge (outflow)

5. Hydrographs showing relation among rate of precipitation, altitude of Mountain Creek Lake (including Cottonwood Bay), and altitude of ground-water levels in wells near Cottonwood Bay, 1992-98

6-15. Maps showing:

6. Distribution of long-term average water levels in the alluvial aquifer

7. Distribution of long-term average saturated thickness in the alluvial aquifer

8. Locations of stabilization systems and recent remediation activity at three Areas of Concern (AOC) ..... 12

9. Configuration of the top of Eagle Ford Shale, which comprises the base of the alluvial aquifer .............. 14

10. Configuration of finite-difference grid and boundary conditions used for the digital computer model of ground-water flow in the alluvial aquifer

11. Calibrated distribution of long-term average infiltration to and long-term average evapotranspiration from the alluvial aquifer

12. Calibrated distribution of hydraulic conductivity in the alluvial aquifer ..............................................

13. Calibrated distribution of transmissivity in the alluvial aquifer under natural (unstressed) conditions .... 21

14. Calibrated distribution of specific yield in the alluvial aquifer ............................................................ 23

15. Comparison of observed and simulated long-term average (steady-state) water levels ........................... 24

16. Distribution of differences between observed and simulated long-term average water levels ................. 25

17. Hydrographs showing comparison of observed (blue) and simulated (red) water levels, 1992-98, for selected wells in the study area

18-20. Maps showing:

18. Comparison of observed and simulated March 1998 water levels

19. Comparison of observed August 1998 water levels and average of water levels observed between August and October 1993-97

20. Comparison of observed and simulated August 1998 water levels

21. Graph showing long-term average monthly and average annual evaporation rates applicable to evaporation losses from the west and east drainage lagoons

22. Graphs showing responses of simulated long-term average water levels to 25-percent increases and 25 -percent decreases in the calibrated values of hydraulic conductivity and the calibrated rates of infiltration in the steady-state model

23. Hydrographs showing responses of simulated water levels in selected observation wells to 50-percent increases (blue) and to 50-percent decreases (green) in the calibrated values (red) of specific yield in the transient model

24. Graph showing schedule of remediation activities during January 1996-December 1998 at Areas of Concern (AOC) 1, 2, and 3

25-27. Maps showing:

25. Simulated distribution of water levels, as of December 31, 1998, following remediation during July 1996-December 1998 at Areas of Concern 1, 2, and 3

26. Simulated distribution of water-level drawdown, as of December 31, 1998, following remediation during July 1996-December 1998 at Areas of Concern 1, 2, and 3

27. Simulated distribution of backward particle-tracking flowlines depicting capture zones in the alluvial aquifer, resulting from 2.5- and 5-year remediation periods at Areas of Concern (AOC) 1,2, and 3 
28-30. Diagrams showing:

28. Simulated rates and directions of ground-water flow, as of December 31, 1998, between northern shoreline of Cottonwood Bay and trench at Area of Concern 3, assuming inactive recovery trench

29. Simulated rates of ground-water discharge, as of December 31, 1998, to recovery trench at Area of Concern 3

30. Simulated rates and directions of ground-water flow, as of December 31, 1998, between northern shoreline of Cottonwood Bay and recovery trench at Area of Concern 3

\title{
TABLES
}

1. Summary of stabilization systems and recent remediation activity at three Areas of Concern (AOC) at the Naval Weapons Industrial Reserve Plant (NWIRP), Dallas, Texas

2. Simulated long-term average (steady-state) rates of recharge to and discharge from the shallow alluvial aquifer underlying the study area

3. Simulated rates of recharge to and discharge from the shallow alluvial aquifer underlying the study area, as of December 31, 1998

4a. Simulated rates of ground-water discharge from the shallow alluvial aquifer underlying the study area, as of December 31, 1998, following remediation during July 1996-December 1998 at Areas of

Concern 1, 2, and 3

4b. Simulated effects on rates of recharge to and discharge from the shallow alluvial aquifer underlying the study area, as of December 31, 1998, following remediation during July 1996-December 1998 at Areas of Concern 1, 2, and 3

\section{VERTICAL DATUM AND ABBREVIATIONS}

Sea Level: In this report, "sea level" refers to the National Geodetic Vertical Datum of 1929—a geodetic datum derived from a general adjustment of the first-order level nets of both the United States and Canada, formerly called Sea Level Datum of 1929.

\section{Abbreviations:}

\author{
acre-ft, acre-foot \\ $\mathrm{ft}$, foot \\ $\mathrm{ft} / \mathrm{d}$, foot per day \\ $\mathrm{ft} / \mathrm{ft}$, foot per foot \\ $\mathrm{ft} / \mathrm{mi}$, foot per mile \\ $\mathrm{ft}^{2} / \mathrm{d}$, foot squared per day \\ $\mathrm{ft}^{3} / \mathrm{d}$, cubic foot per day \\ $\mathrm{gal} / \mathrm{min}$, gallon per minute \\ in/yr, inch per year \\ mi, mile \\ $\mathrm{mi}^{2}$, square mile
}




\title{
Computer-Model Analysis of Ground-Water Flow and Simulated Effects of Contaminant Remediation at Naval Weapons Industrial Reserve Plant, Dallas, Texas
}

\author{
By René A. Barker and Christopher L. Braun
}

\section{Abstract}

In June 1993, the Department of the Navy, Southern Division Naval Facilities Engineering Command (SOUTHDIV), began a Resource Conservation and Recovery Act (RCRA) Facility Investigation (RFI) of the Naval Weapons Industrial Reserve Plant (NWIRP) in north-central Texas. The RFI has found trichloroethene, dichloroethene, vinyl chloride, as well as chromium, lead, and other metallic residuum in the shallow alluvial aquifer underlying NWIRP.

These findings and the possibility of on-site or off-site migration of contaminants prompted the need for a ground-water-flow model of the NWIRP area. The resulting U.S. Geological Survey (USGS) model: (1) defines aquifer properties, (2) computes water budgets, (3) delineates major flowpaths, and (4) simulates hydrologic effects of remediation activity. In addition to assisting with particle-tracking analyses, the calibrated model could support solute-transport modeling as well as help evaluate the effects of potential corrective action. The USGS model simulates steadystate and transient conditions of ground-water flow within a single model layer.

The alluvial aquifer is within fluvial terrace deposits of Pleistocene age, which unconformably overlie the relatively impermeable Eagle Ford Shale of Late Cretaceous age. Over small distances and short periods, finer grained parts of the aquifer are separated hydraulically; however, most of the aquifer is connected circuitously through randomly distributed coarser grained sediments. The top of the underlying Eagle Ford Shale, a regional confining unit, is assumed to be the effective lower limit of ground-water circulation and chemical contamination.

The calibrated steady-state model reproduces long-term average water levels within +5.1 or -3.5 feet of those observed; the standard error of the estimate is 1.07 feet with a mean residual of 0.02 foot. Hydraulic conductivity values range from 0.75 to 7.5 feet per day, and average about 4 feet per day. Specific yield values range from 0.005 to 0.15 and average about 0.08 . Simulated infiltration rates range from 0 to 2.5 inches per year, depending mostly on local patterns of ground cover.

Computer simulation indicates that, as of December 31, 1998, remediation systems at NWIRP were removing 7,375 cubic feet of water per day from the alluvial aquifer, with 3,050 cubic feet per day coming from aquifer storage. The resulting drawdown prevented 1,800 cubic feet per day of ground water from discharging into Cottonwood Bay, as well as inducing another 1,325 cubic feet per day into the aquifer from the bay. An additional 1,200 cubic feet of water per day (compared to pre-remediation conditions) was prevented from discharging into the west lagoon, east lagoon, Mountain Creek Lake, and Mountain Creek swale.

Particle-tracking simulations, assuming an aquifer porosity of 0.15 , were made to delineate flowpath patterns, or contaminant "capture zones," resulting from 2.5- and 5-year periods of remediation activity at NWIRP. The resulting flowlines 
indicate three such zones, or areas from which ground water is simulated to have been removed during July 1996-December 1998, as well as extended areas from which ground water would be removed during the next 2.5 years (January 1999June 2001).

Simulation indicates that, as of December 31,1998 , the recovery trench was intercepting about 827 cubic feet per day of ground water that-without the trench-would have discharged into Cottonwood Bay. During this time, the trench is simulated to have removed about 3,221 cubic feet per day of water from the aquifer, with about 934 cubic feet per day (29 percent) coming from the south (Cottonwood Bay) side of the trench.

\section{INTRODUCTION}

The Department of the Navy, Southern Division Naval Facilities Command (SOUTHDIV), since June 1993 has conducted a Resource Conservation and Recovery Act (RCRA) Facility Investigation (RFI) of the Naval Weapons Industrial Reserve Plant (NWIRP), in north-central Texas (fig. 1). The RFI (EnSafe/Allen \& Hoshall, 1996) documented the presence of trichloroethene (TCE), dichloroethene (DCE), vinyl chloride (VC), as well as chromium, lead, and other metallic residuum in the shallow alluvial aquifer underlying NWIRP. These findings, together with the possibility of on-site and off-site migration of contaminants, prompted a series of studies_-beginning in June 1994by the U.S. Geological Survey (USGS) to supplement the results of concurrent work by the Navy's private consulting firm, EnSafe, Inc. (formerly EnSafe/Allen \& Hoshall).

\section{Purpose and Scope}

The Navy's need for a computer model of ground-water flow was prompted by the RFI's discovery of chlorinated organic compounds in the alluvial aquifer underlying NWIRP and its objective to "characterize the facility and its geology and hydrogeology," in accordance with the U.S. Environmental Protection Agency (EPA) Superfund regulations. Accordingly, the USGS model was developed to: (1) define the hydraulic properties of the aquifer; (2) compute water budgets that quantify major components of recharge and discharge; (3) delineate preferential routes of ground-water flow (flowpaths); and (4) simulate the effects of recent remediation activity and predict the results of potential corrective action. In addition to supporting particle-tracking analysis, this finite-difference model incorporates the numerical template for a solutetransport model, if and when such a model becomes necessary.

This report was written to document the model as well as to summarize the requisite methodologies and the resulting benefits and limitations. Providing simulated distributions of both actual and hypothetical conditions, the report should help the Navy assess the effects of actual, as well as potential, remediation systems and evaluate the possibility of contaminant migration associated with NWIRP operations.

\section{Study Area}

The study area (fig. 1), within which NWIRP is roughly centered, straddles two surface-water bodies: the West Fork Trinity River on the north and Mountain Creek Lake on the south (fig. 2). Extending southward from the Dallas, Texas, suburb of Grand Prairie, the study area includes Cottonwood Creek, Cottonwood Bay, and the northwestern part of Mountain Creek Lake (fig. 3). Mostly a perennial stream below altitudes of about $460 \mathrm{ft}$ above sea level, Cottonwood Creek drains into Cottonwood Bay. Cottonwood Bay is a truncated arm of what once connected directly with Mountain Creek Lake across an area now supporting runways at the adjacent Naval Air Station (NAS). Beginning about 1949 (EnSafe/Allen \& Hoshall, 1997, p. 4-13), the main runway of reinforced concrete was extended southward atop fill that isolated Cottonwood Bay from Mountain Creek Lake, a 25,000-acre-ft impoundment used for public recreation and as a cooling reservoir by Texas (electric) Utilities. Consequently, an artificial channel was cut through bedrock to reconnect Cottonwood Bay and Mountain Creek Lake, whose pool levels averaged $456.7 \mathrm{ft}$ above sea level during 1992-98.

NWIRP (314 acres) began manufacturing military and commercial aircraft shortly after opening in 1941. Northrup Grumman has operated this government-owned, contractor-operated facility since 1994. The eastern boundary of NWIRP abuts the northwestern boundary of NAS (837 acres). NAS has 


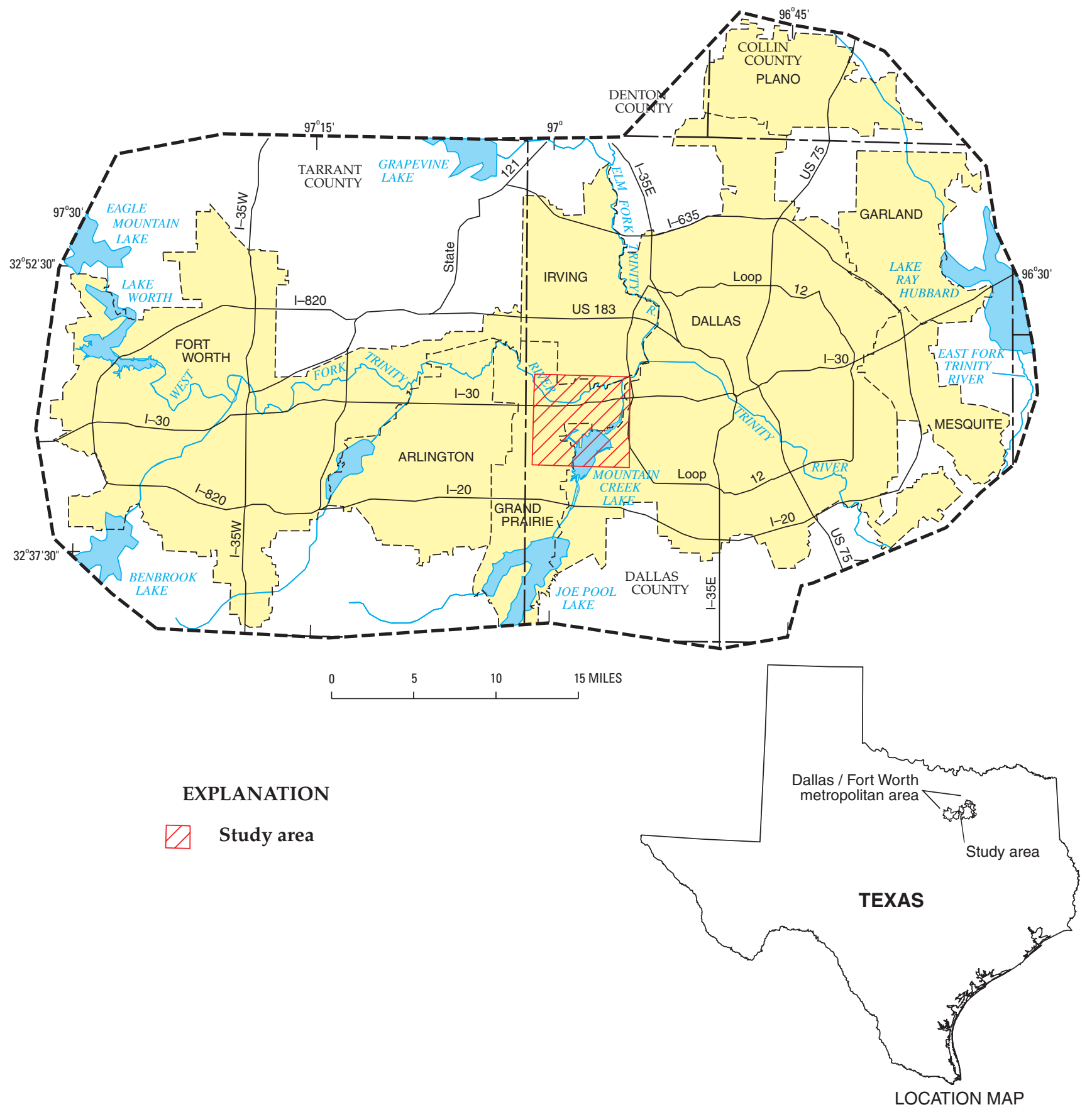

Figure 1. Location of study area.

been closed since 1993 under guidelines established by the Base Realignment and Closure Act (BRAC) of 1988.

The west and east drainage lagoons (fig. 3), which were constructed primarily for stormwater and wastewater control during the early 1940s, historically have received metal-tainted sludge and organic pollutants from plant operations - as well as stormwater and wastewater outflow (EnSafe/Allen \& Hoshall, 1996). In addition to TCE, DCE, and VC in the ponded water, the lagoon sediments contain metals, pesticides, petroleum hydrocarbons, polychlorinated biphenyls (PCBs), 


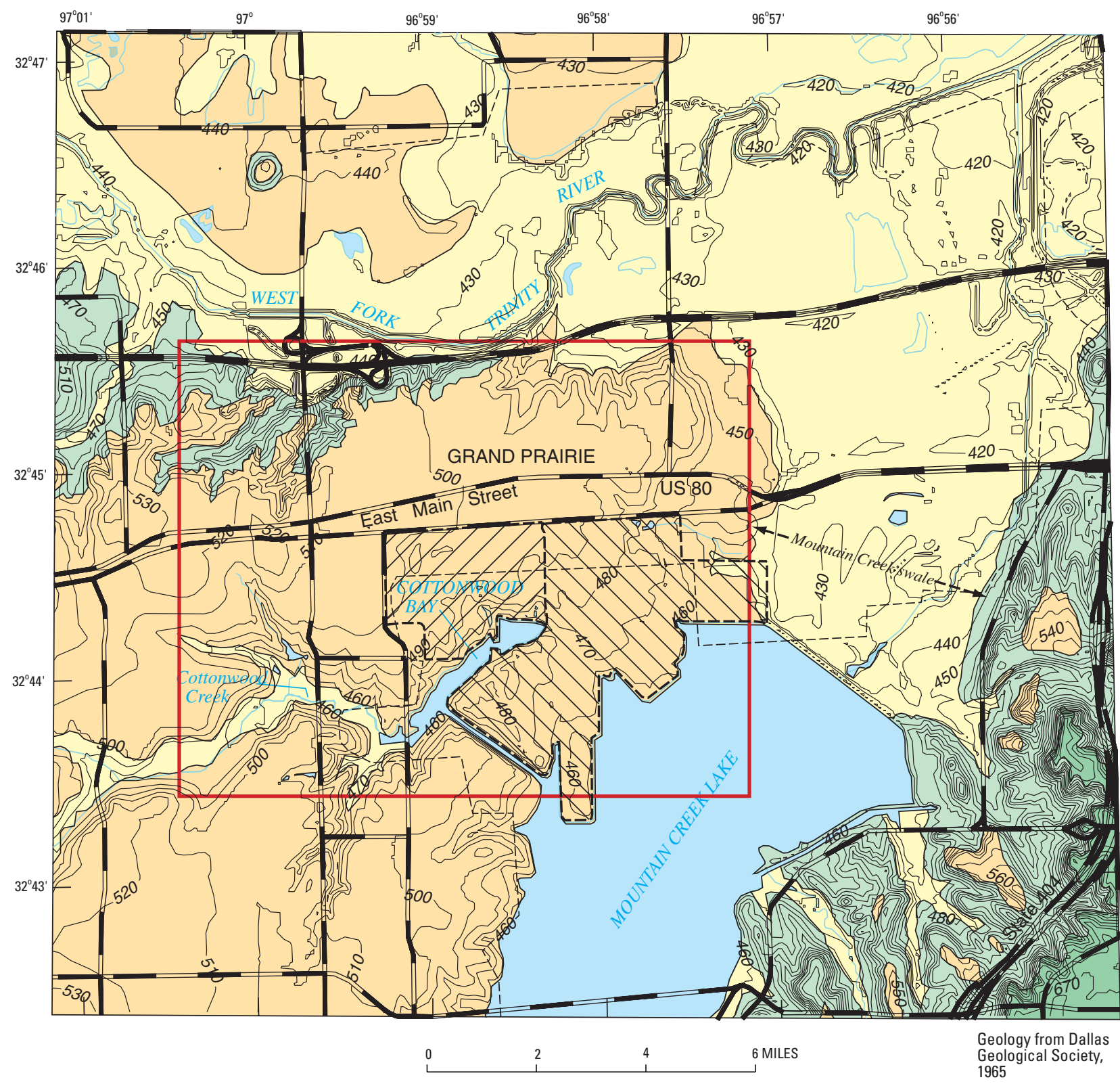

EXPLANATION

Austin Group

Pleistocene terrace deposits

Eagle Ford Shale, undifferentiated
Quaternary alluvial or flood- - $500-$ plain deposits

Naval Weapons Industrial

Reserve Plant

Naval Air Station
Topographic contourShows altitude of land surface. Contour interval 10 feet. Datum is sea level

Limits of model area

Figure 2. Locations of Naval Weapons Industrial Reserve Plant, Naval Air Station, and off-site water bodies.

volatile organic compounds (VOCs), and semivolatile organic compounds (SVOCs). Beginning in 1993, operations were altered to minimize the discharge of metal and fluid contaminants into all surface-water bodiesincluding the topographically low, occasionally dry lagoonal areas. 


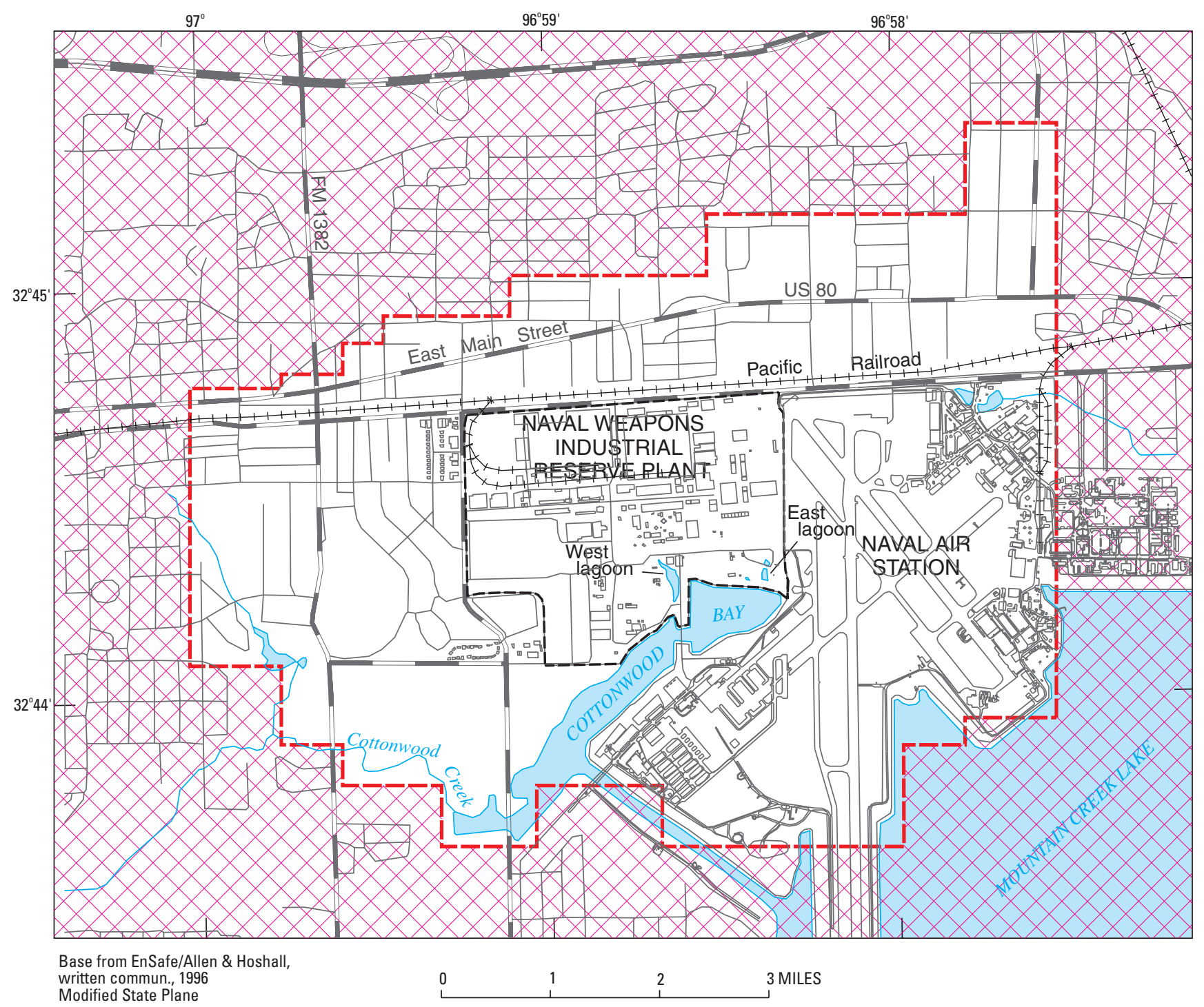

\section{EXPLANATION}

[- Active model area

Inactive model area

Figure 3. Locations of model area, roads, railroads, runways, on-site water bodies, and buildings associated with Naval Weapons Industrial Reserve Plant and Naval Air Station.

\section{Methods of Investigation}

\section{Digital Computer Model}

Ground-water conditions in and around NWIRP were simulated primarily with two sets of FORTRAN computer code: MODFLOW (McDonald and
Harbaugh, 1988; Harbaugh and McDonald, 1996) and MODPATH (Pollock, 1989). Ground-water gradients simulated with MODFLOW were combined with the particle-tracking capability of MODPATH to delineate contaminant "capture zones" with which to assess the areal extent of remediation activity at NWIRP. 
MODFLOW uses a form of digital (numerical) processing known as finite-difference approximation to solve partial differential equations of groundwater flow. The USGS model was adapted for NWIRP through its use of the following "modules," or MODFLOW packages: Basic; Output Control; Block-Centered-Flow; Drain; River; EVT (evapotranspiration); Recharge; and SIP (numerical solver).

Output from the calibrated MODFLOW model was used as input to MODPATH to track imaginary particles of water backward in time and space (Alley, 1993, p. 37, 597). The accuracy with which the particletracking program delineates the effects of remediation activity depends on the accuracy of steady-state groundwater gradients and flow rates simulated beforehand with MODFLOW.

Other USGS-supported, FORTRAN-based computer software, such as ZONEBUDGET (A.W. Harbaugh, U.S. Geological Survey, written commun., 1990) and HYPOST (S.A. Leake, U.S. Geological Survey, written commun., 1998), were used as postprocessors to cull specific results from MODFLOW output. These ancillary programs aided with the compilation, as well as with the interpretation, of most of the water-level and water-budget data discussed herein.

\section{Data Collection, Storage, and Retrieval}

The USGS model was developed within the framework of a Geographic Information System (GIS), known as ARC-INFO, which supported data collection, storage, and retrieval. Data collected and retrieved in various formats were stored as ARC-INFO coverages in upper-level directories depending on whether the primary attributes were hydrologic, geologic, political, or cultural in nature. GIS methodology was used during all phases of model development, including model calibration and the analysis of actual and hypothetical conditions at NWIRP.

The project basemap, which covers nearly $6 \mathrm{mi}$ (east-west) by $4 \mathrm{mi}$ (north-south) of project area, was digitized from USGS 7.5-minute quadrangle (Arlington, Duncanville, Euless, and Irving) maps. The latest distributions of major roads, railroads, and surface-water bodies were downloaded from the Internet (U.S. Geological Survey, 2000) as digital line graph (DLG) data. Details of the NWIRP facility, including the minor roads and the storm drainage system, were incorporated into the basemap from blueprints, schematic diagrams, and Computer Aided Drafting and
Design (CADD) files retrieved from EnSafe. All map features were field checked as necessary.

Early in 1997 and again in 1998, USGS personnel canvassed areas adjacent to NWIRP for wells from which water levels could be measured in the shallow alluvial aquifer. Nearly 20 new water-level measurements were obtained north and west of the plant. These data were used to establish the distribution of simulated boundary conditions for the northern and southwestern margins of the NWIRP/NAS compound.

Sources of precipitation data include 1992-95 climatological records for NAS (previously called Hensley Field) and correlative 1992-98 data triangulated from National Oceanic and Atmospheric Administration (NOAA) weather stations at Arlington (Dallas Federal Aviation Agency [FAA]) and at Joe Pool Lake (U.S. Department of Commerce, 2000).

\section{Acknowledgments}

The authors appreciate EnSafe's cooperative spirit and timely responses to the USGS requests for hydrogeologic data with which to establish the digital databases necessary for model development, calibration, and maintenance. Jeff James, EnSafe project manager at NWIRP, was particularly helpful in obtaining relevant data.

\section{Hydrogeologic Setting}

Figure 4 is a generalized depiction of surface and subsurface features in the primary area of interest, or model area (fig. 2). Arrows indicate major components of ground-water inflow and outflow: blue arrows for recharge, primarily from infiltrated precipitation, and magenta for discharge, primarily to downgradient surface-water bodies. The associated long-term average rates of ground-water flow-rounded to the nearest $0.5 \mathrm{gal} / \mathrm{min}$ - are estimated from the results of model analysis, discussed under "Computer-Model Analysis of Ground-Water Flow."

Land-surface altitudes in the model area range from about $525 \mathrm{ft}$ above sea level atop the ridge in the northwestern part of the area to less than $440 \mathrm{ft}$ along the wide depression containing Mountain Creek, herein called the Mountain Creek swale, on the east. The shoreline altitudes of Cottonwood Bay and Mountain Creek Lake typically are within +1 or $-2 \mathrm{ft}$ of $457 \mathrm{ft}$ above sea level, as seen from the plot of pool altitudes in figure 5 . 


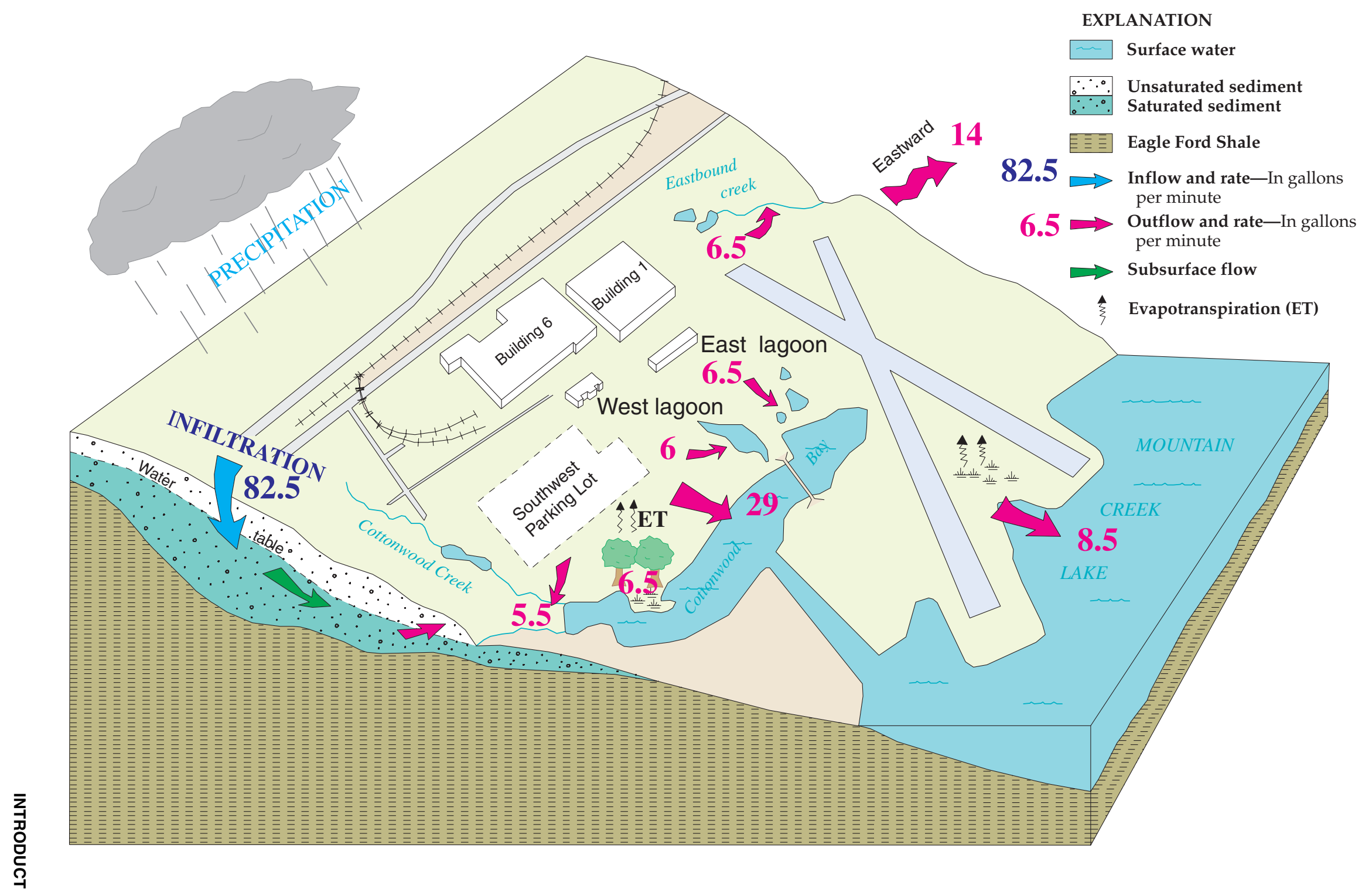

Figure 4. Diagrammatic section showing conceptualized hydrogeologic setting and estimated long-term average rates of ground-water recharge (inflow) and discharge (outflow). 

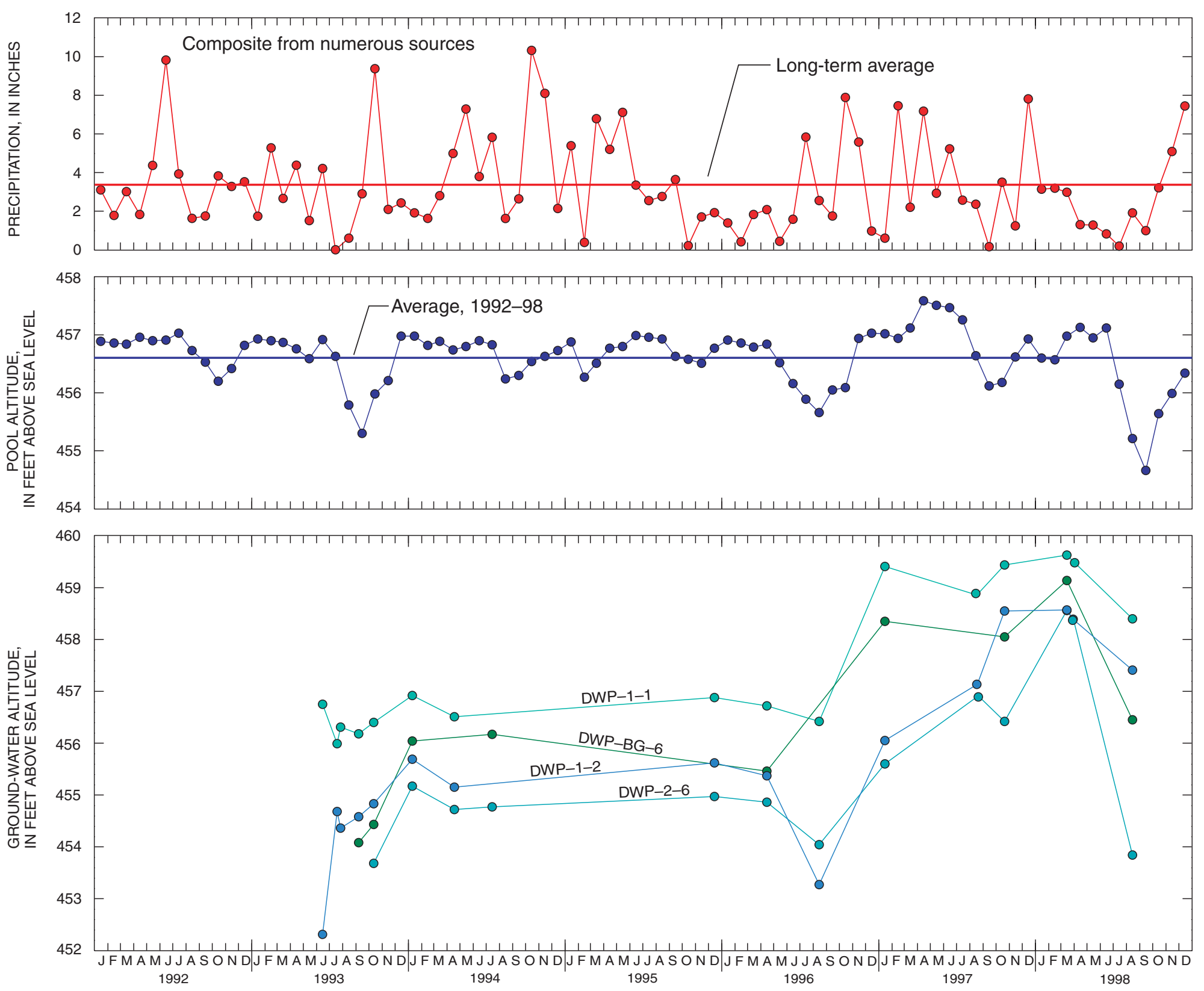

Figure 5. Hydrographs showing relation among rate of precipitation, altitude of Mountain Creek Lake (including Cottonwood Bay), and altitude of ground-water levels in wells near Cottonwood Bay, 1992-98. 


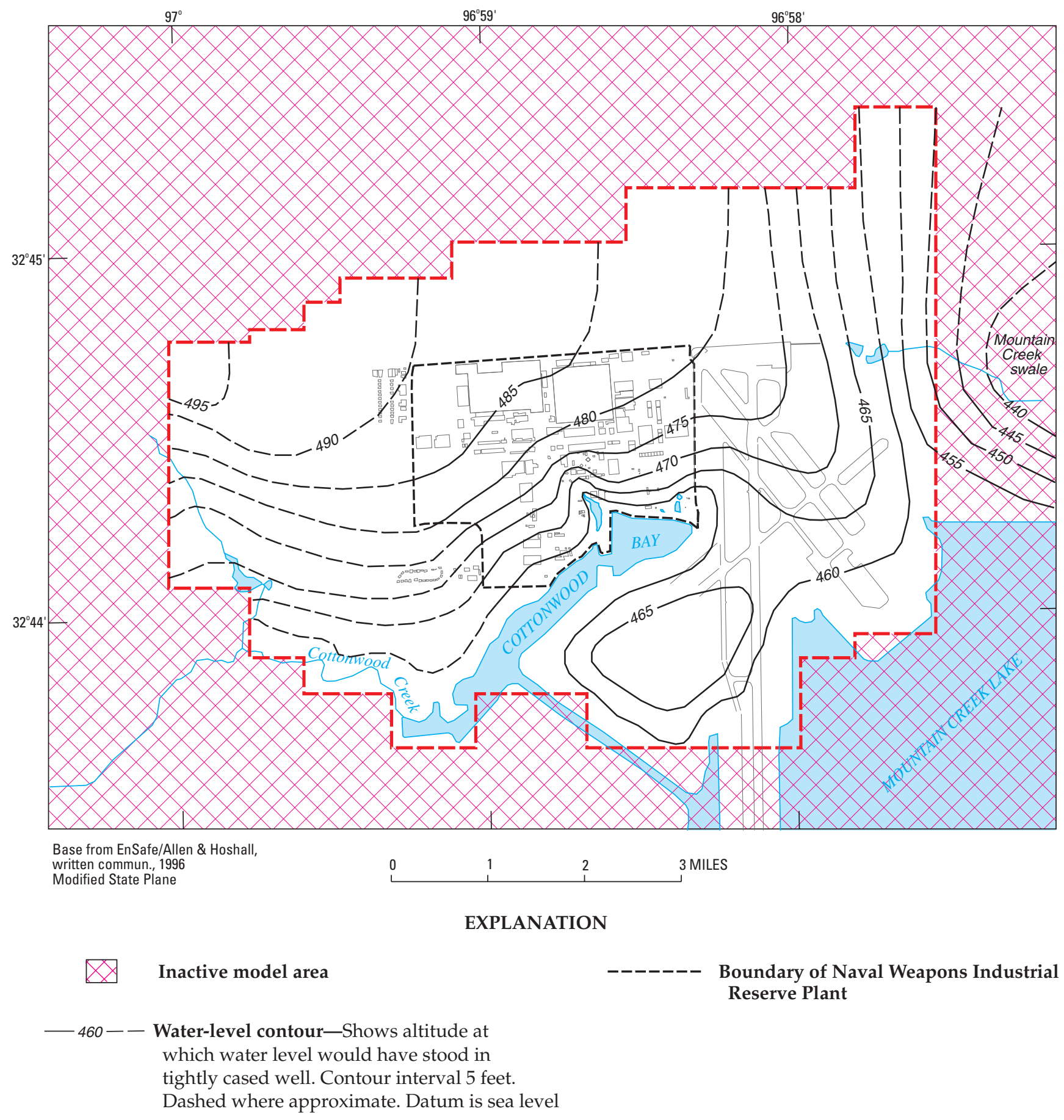

Figure 6. Distribution of long-term average water levels in the alluvial aquifer.

The source of most ground water is precipitation, which averages about 36 in/yr (Owenby and Ezell, 1992). Precipitation most readily infiltrates the porous higher-altitude areas around the northern limits of the NWIRP/NAS compound (fig. 4, left). Relatively little precipitation infiltrates the lower-altitude areas, or parts of the aquifer that directly underlie the larger buildings or the more extensive concrete and tarmac surfaces.

The water table, which slopes mostly southeastward toward Cottonwood Bay and Mountain Creek Lake (fig. 6), generally lies 10 to $20 \mathrm{ft}$ below land surface across the northern two-thirds of the NWIRP/NAS 
compound. As the aquifer thins southward, however, and the proportion of relatively porous sediment reduces, the water table approaches land surface and ultimately equilibrates with the area's lower-lying surface-water bodies.

Ultimately, most ground water discharges into these downgradient drains, thereby helping to maintain more-or-less constant pool levels in Cottonwood Bay, which is connected to Mountain Creek Lake. Some ground water discharges into the west and east drainage lagoons before it reaches Cottonwood Bay. Some ground water moves from NWIRP, eastward beneath NAS, toward the depressed Mountain Creek swale (figs. 2, 6), which is characterized by the lowest altitudes in the study area. Some ground water is lost through evapotranspiration in the shallowest depth-towater areas, where grasses, aquatic plants, and willow and cottonwood trees withdraw water directly from the saturated zone.

The cross section in figure 4 depicts a bedrock floor, or presumed lower limits of meaningful groundwater circulation and substantial chemical contamination. Composed of the Eagle Ford Shale, this bedrock is considered one of the least permeable rock formations in Texas (E.T. Baker, Jr., U.S. Geological Survey, written commun., 1999).

\section{Shallow Alluvial Aquifer}

The shallow alluvial aquifer underlying the study area is within fluviatile terrace deposits of Pleistocene age that unconformably overlie the relatively steeply dipping and comparatively impermeable Eagle Ford Shale of Late Cretaceous age (University of Texas, 1987). EnSafe/Allen \& Hoshall (1994) recognized three complexly distributed water-yielding units, composed mostly of silty sand, separated by two discontinuous zones of less permeable silty clay. On the basis of the results of short-term (1-hour) aquifer tests (P.T. Stanley, EnSafe, Inc., oral commun., 1997), parts of the aquifer appear to be separated hydraulically. Nevertheless, geophysical logs (Braun and others, 2000) and long-term water-level records indicate that most parts of this semiconfined-to-unconfined aquifer are connected hydraulically, albeit circuitously in places.

The reader is referred to EnSafe/Allen \& Hoshall $(1994,1996,1997)$ for detailed descriptions of NWIRP and NAS geologic settings, including maps and detailed profiles of so-called upper, intermediate, and lower "fining-upward" lithologic sequences. For comprehen- sive hydrogeologic sections of the sediments and descriptions of their relative clay content and their water-transmitting potential, the reader is referred to Anaya and others (2000).

The map of water-level contours (fig. 6) is a subdued replica of the overlying topography. Groundwater altitudes range from about $495 \mathrm{ft}$ below the ridge in the northwestern part of the model area to about $440 \mathrm{ft}$ near the Mountain Creek swale, on the east (fig. 2). Ground-water gradients, which slope mainly from northwest to southeast, steepen from less than $5 \mathrm{ft} / \mathrm{mi}$ near the ground-water divide (underlying East Main Street, fig. 3) to about 12 to $15 \mathrm{ft} / \mathrm{mi}$ near Cottonwood Bay. Although most of the ground water is moving laterally, vertical gradients-typically less than $0.1 \mathrm{ft} / \mathrm{ft}$ under natural conditions (P.T. Stanley, EnSafe, Inc., oral commun., 1997)—indicate that permeability does vary, and that some water does seep, vertically within the aquifer. Downward seepage prevails in the northern, topographically high recharge area. Upward gradients near the west and east lagoons and along the shorelines of Cottonwood Bay and Mountain Creek Lake indicate diffuse upward discharge is occurring to these low-lying surface-water bodies. The Mountain Creek swale, Cottonwood Bay, and Mountain Creek Lake are the major discharge areas in the study area.

The saturated thickness of the shallow alluvial aquifer is equal to the difference between the altitude of the water table and the altitude of the Upper Cretaceous bedrock. The distribution of saturated thickness shown in figure 7 results from subtracting the top of the Eagle Ford Shale from the long-term average water levels (fig. 6). The areal variation in saturated thickness is determined largely by the relief on this erosional, bedrock surface. Saturated thickness ranges from less than $10 \mathrm{ft}$ around the eastern and western margins of the model area to nearly $60 \mathrm{ft}$ near the NWIRP midsection. The greatest thicknesses result from an erosional (now buried) channel that, from the northern part of NAS, trends generally southwestward and southward near the NWIRP midsection. The thinly saturated areas around the perimeter of the model area are considered "bottlenecks" to ground-water flow, as they impede groundwater circulation.

In an attempt to minimize the spread of VOCs in the ground water at NWIRP (EnSafe/Allen \& Hoshall, 1994), a RCRA Part B permit and stabilization work plan was approved on March 8, 1995, to initiate remediation measures (EnSafe/Allen \& Hoshall, 1997, p. 1-1). In January 1996, Morrison and Knudsen 


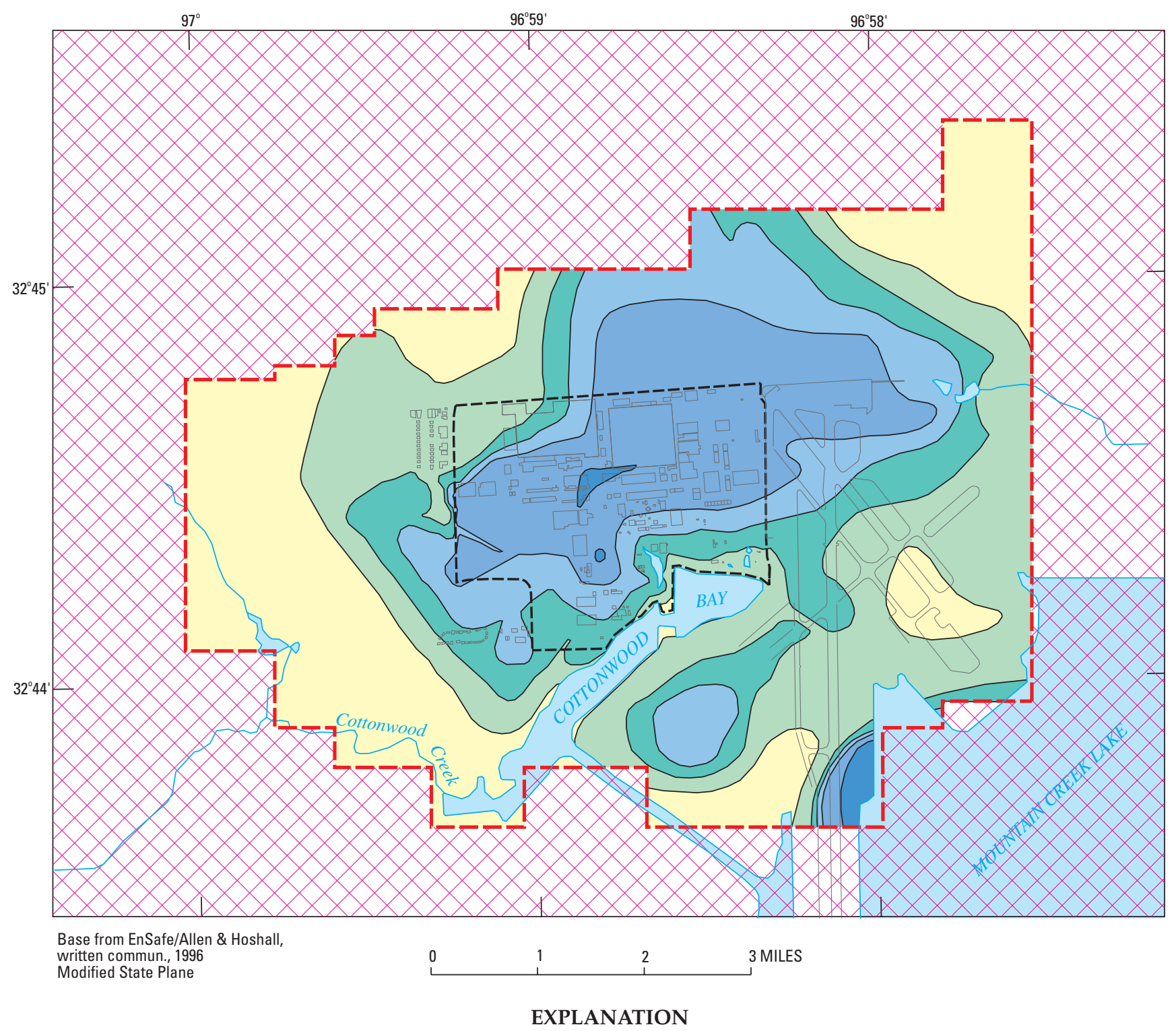

Saturated thickness, in feet
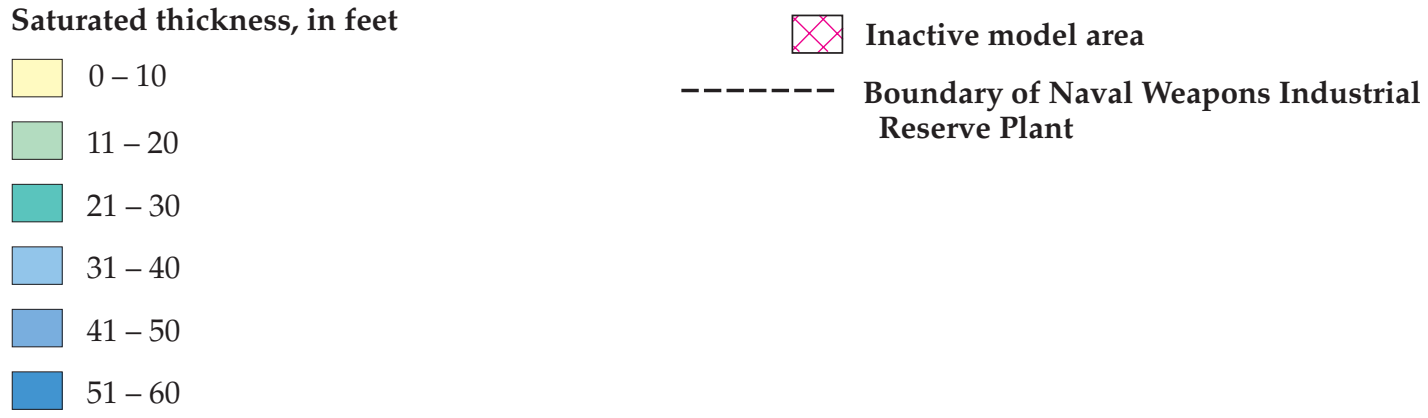

Boundary of N
Reserve Plant

Figure 7. Distribution of long-term average saturated thickness in the alluvial aquifer.

Corporation began construction of stabilization systems designed to extract contaminated ground water from three Areas of Concern (AOC). Completed in June
1996, the systems were first operated in July 1996. However, various "routine" mechanical problems delayed the start of full-time remediation until at least 

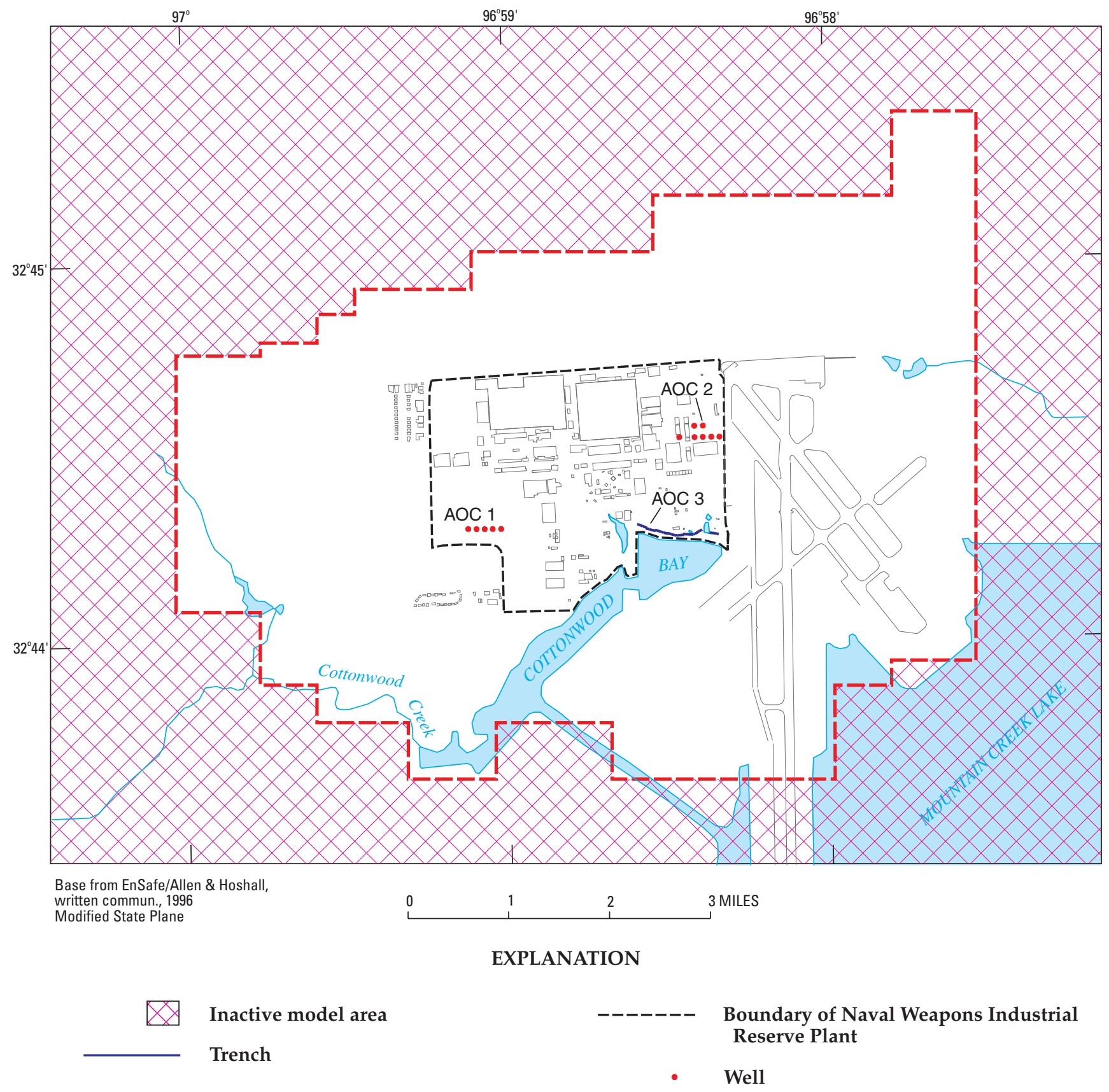

Figure 8. Locations of stabilization systems and recent remediation activity at three Areas of Concern (AOC).

January 1997 (EnSafe/Allen \& Hoshall, 1997, p. 3-1). Table 1 summarizes the stabilization systems at AOCs 1, 2, and 3 (fig. 8) and the associated remediation activity.

\section{Eagle Ford Shale}

The Eagle Ford Shale directly underlies the terrace alluvium at NWIRP. This formation ranges from about 150 to about $185 \mathrm{ft}$ thick at NWIRP (Jones and Paillet, 1997, p. 2). The exceedingly fine-grained composition of the Eagle Ford Shale (University of Texas, 1987) makes its hydraulic conductivity about 1,000 times less than that of the underlying Woodbine aquifer and, perhaps 100 to 1,000 times less than the hydraulic conductivity of the overlying shallow alluvial aquifer. The Eagle Ford Shale is considered a confining 
Table 1. Summary of stabilization systems and recent remediation activity at three Areas of Concern (AOC) at the Naval Weapons Industrial Reserve Plant (NWIRP), Dallas, Texas

\author{
Southwest parking lot: AOC 1 \\ 1. Five (4-inch) recovery wells, installed to base of shallowest water-yielding zone. \\ 2. Located in southwestern part of NWIRP; concrete-covered area used for employee parking. \\ 3. No volatile organic compound (VOC) sources; however, several upgradient sources detected. \\ 4. Vertical interconnection weak among mapped water-yielding zones. \\ 5. Chlorinated solvents probably migrating southward-probably off-site, possibly toward residential area. \\ 6. Water is pumped to on-site treatment system, stripped of VOCs, and routed to sanitary sewer. \\ 7. Pumping rates averaging from about 8 gallons per minute (July 1996-June 1997) to about 11 gallons per minute (July 1997-December \\ 1998).
}

\title{
Waste petroleum, oil, and lubricant (POL) site: AOC 2
}

1. Seven (4-inch) recovery wells, installed through all water-yielding zones.

2. Located near eastern boundary of NWIRP, adjacent to Naval Air Station (NAS), in grassy field surrounded by concrete pavement.

3. No VOC sources; however, several upgradient sources detected.

4. Distribution of underlying sediments is complex: vertical interconnection likely.

5. Chlorinated solvents probably migrating southward, and possibly eastward toward NAS.

6 . Formerly the headwaters of small drainage feeding east lagoon; backfilled during 1940s-50s.

7. Water is pumped to on-site treatment system, stripped of VOCs, and routed to sanitary sewer.

8. Pumping rates averaging from about 11 gallons per minute (July 1997-December 1998) to about 14 gallons per minute (July 1996-June 1997).

\section{Recovery Trench: AOC 3}

1. Six trench segments, totaling about 1,500 feet in length; installed above Eagle Ford Shale.

2. Located just north of northernmost shore of Cottonwood Bay.

3. No VOC sources; however, several upgradient sources detected.T

4. Chlorinated solvents probably migrating southward, toward Cottonwood Bay.

5. Trench objective is to intercept contaminated ground water before it reaches Cottonwood Bay.

6. Recovered water is pumped to nearby treatment system, stripped of VOCs, and routed to sanitary sewer.

7. Drain recovery ranges typically between 15 to 20 gallons per minute.

unit by virtue of its capacity to impede ground-water movement.

The Eagle Ford Shale is important to the groundwater conditions at NWIRP to the extent that the relief of its upper surface (fig. 9) affects the saturated thickness and, therefore, the transmissivity of the alluvial aquifer. An L-shaped erosional trough, about 400 to $800 \mathrm{ft}$ wide with shale altitudes of less than $430 \mathrm{ft}$ above sea level, extends from northwest NAS westward toward the NWIRP midsection before bending southward and trending almost to Cottonwood Bay (EnSafe/Allen \& Hoshall, 1996, p. 4-20). Some of the largest transmissivity values in the study area correspond to this bedrock channel. Accordingly, some of the smallest transmissivity values correlate with the area's highest shale altitudes.

\section{COMPUTER-MODEL ANALYSIS OF GROUND-WATER FLOW}

The USGS model simulates steady-state and transient conditions of ground-water flow within a single aquifer, or model layer. A multi-layered model of three-dimensional conditions was attempted initially; however, the scarcity of hydrogeologic data with which to define such conditions impeded progress to the extent that the attempt was eventually abandoned. Attempts to subdivide the relatively shallow saturated thickness (everywhere less than $60 \mathrm{ft}$ ) into three separate layers yielded results that frequently were numerically unstable and (or) hydraulically unreliable. Single-layer simulations, assuming unconfined-to-semiconfined aquifer conditions, were adequate for simulating hydrologic conditions at NWIRP. 


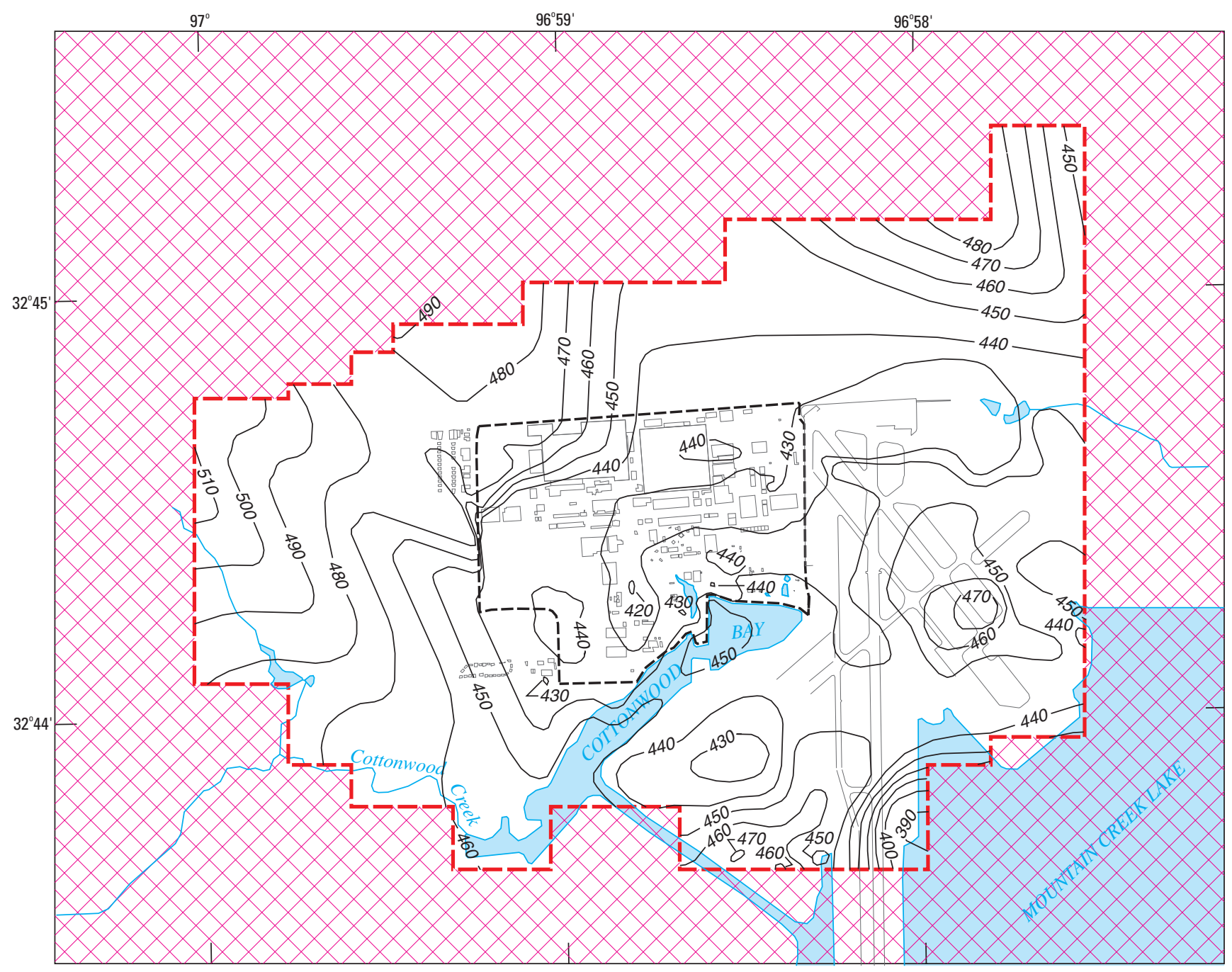

Base from EnSafe/Allen \& Hoshall, written commun., 1996

0 1 2 3 MILES

\section{EXPLANATION}

$\$$ Inactive model area

— 460 - Top-of-confining-unit contour-Shows altitude of top of Eagle Ford Shale. Contour interval 10 feet. Datum is sea level

Figure 9. Configuration of the top of Eagle Ford Shale, which comprises the base of the alluvial aquifer.

\section{Model Description}

Because no model can adequately represent the entire hydrogeologic environment, the extent and objectives of the computer model must be limited to finite, definable parts of that environment. A finitedifference grid is used to subdivide the relevant parts of the ground-water-flow system into a numerical framework of discrete, but manageable parts. In addition to providing the spatial discretization for numerical 
analysis, this grid links the ARC-INFO database to the model to facilitate the compilation and maintenance of model input data. For example, delineations of low clay-content, intermediate clay-content, and high claycontent sediment subdivisions of the aquifer (Anaya and others, 2000) were translated into ARC coverages (digital maps) of permeability and storativity. These coverages were then intersected with the model grid to ascertain initial values of hydraulic conductivity and specific yield for each active cell of the model.

The finite-difference grid consists of variably dimensioned rows and columns-numbering 180 and 212 , respectively - to provide a total of 38,160 cells (fig. 10). The smallest of the resulting cells-positioned over NWIRP, the principal area of interest-measure $25 \mathrm{ft}$ to a side and total 30,400 . From the comparatively tight inner mesh, cell dimensions increase progressively outward to help isolate the simulated conditions of interest from error inherent in the specification of distant boundary conditions. The largest cells, comprising the grid corners (fig. 10), are slightly more than $1 \mathrm{mi}^{2}$ in area.

\section{Calibration Strategy}

The USGS model was calibrated to simulate long-term average (steady-state), as well as timedependent (transient) ground-water conditions in and around NWIRP. During calibration, the input data were adjusted (within the limits of sound judgment and a reasonable amount of variability) to minimize differences between observed and simulated hydrologic conditions. Initially, the comparatively well-defined input data, such as the hydraulic boundaries and saturated thicknesses, were incorporated into a largely conceptual prototype of the final, calibrated model. The differences between simulated and observed water-level and waterbudget conditions were used in combination with fundamental principles of hydrogeology to more accurately represent the less-well-defined data, such as the aquifer properties and rates of recharge and discharge.

The calibrated input data incorporate refinements to previously unpublished and some published data on hydraulic conductivity (or transmissivity), specific yield, infiltration, drain outflow, and evapotranspiration. Although refined through calibration, the hydraulic-conductivity (or transmissivity) data reflect the recent findings of geophysical mapping by the USGS and aquifer testing by EnSafe. The final distributions of specific-yield, infiltration, drain-outflow, and evapotranspiration data result mostly from the outcome of trial-and-error calibration.

Once it was demonstrated that the model could approximate observed historical conditions, it was then used to simulate the effects of conditions that were not used during calibration. The model could be used in the future to simulate the likely effects of changes in the simulated system, either natural or proposed. Thus, the effects of increases or decreases in the rates of recharge or discharge because of flooding or drought or perhaps in response to alternative remedial actions might be evaluated.

\section{Boundary Conditions}

Boundary conditions (fig. 10) are specified to represent hydraulic conditions outside the 35,192 actively simulated cells that represent the principal area of interest. In addition to assuming that the top of the Eagle Ford Shale is the lower limit of ground-water flow, boundary conditions are applied to 2,751 no-flow cells and 217 specified-head cells. The specified-head cells along the southeastern edge of the model grid coincide with the near-constant stage of Mountain Creek Lake and its connected waterways. The north-south group of specified-head cells that constitutes the easternmost column of the model grid corresponds with the Mountain Creek swale (figs. 2, 6), a prominent groundwater drain. All other boundaries are no-flow cells through which no water enters or leaves the active part of the model. The no-flow cells in the west correspond to discharge areas controlled by Cottonwood Creek or to areas with water-level contours indicating negligible east-west flow (fig. 6). The no-flow boundary along the northern limits of the model area approximates the effects of a ground-water divide that underlies the topographic divide just north of East Main Street (figs. 2, 3).

\section{Recharge}

Recharge to the alluvial aquifer occurs as water from precipitation percolates through the unsaturated zone to the water table, completing the process of ground-water infiltration. The rate of simulated infiltration is limited to the difference between the rates of precipitation and water lost through runoff and evapotranspiration (below). Precipitation averages about 36 in/yr in the Grand Prairie area (Owenby and Ezell, 1992), where runoff averages about $4 \mathrm{in} / \mathrm{yr}$ (U.S. Geological Survey, 1986, fig. 1) and evapotranspiration is assumed to average about $30 \mathrm{in} / \mathrm{yr}$ (Larkin and 


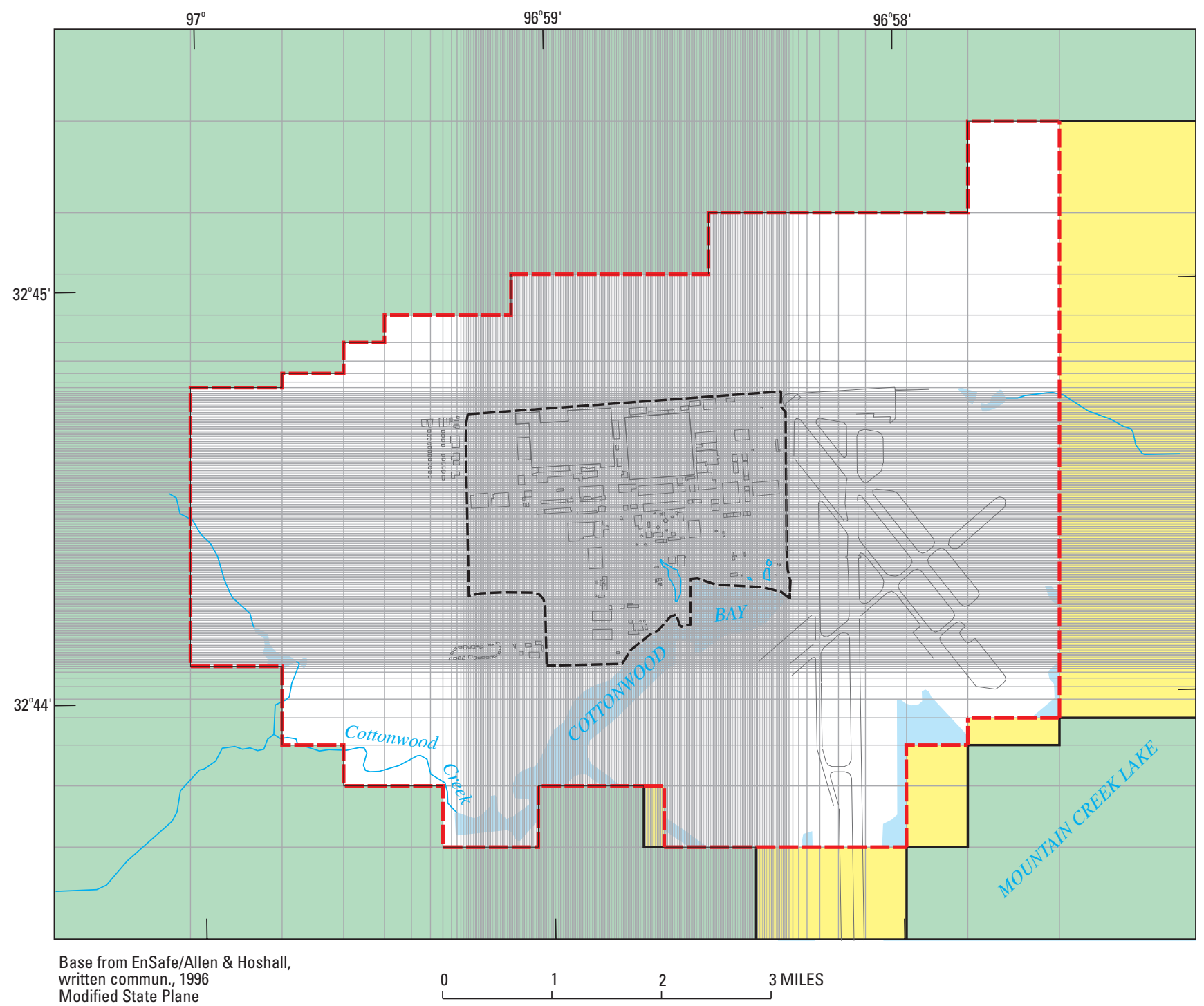

EXPLANATION

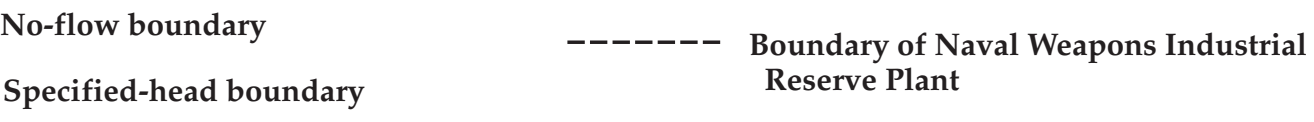

Figure 10. Configuration of finite-difference grid and boundary conditions used for the digital computer model of ground-water flow in the alluvial aquifer.

Bomar, 1983). Therefore, infiltration was estimated initially to average about $2 \mathrm{in} / \mathrm{yr}$.

Initially limited to $2 \mathrm{in} / \mathrm{yr}$, the simulated infiltration was distributed areally on the basis of ground cover. For example, parts of the aquifer covered with grass received the maximum $2 \mathrm{in} / \mathrm{yr}$, whereas those parts covered by roads or runways received zero infiltration. As calibration progressed, however, it became necessary to adjust infiltration rates to more appropriately account for the effects of less obvious conditions, such as ground slope, soil type, and (or) on-site water sources. Calibration eventually necessitated that infiltration be simulated for some parts of the study area that originally had been assumed impervious to 


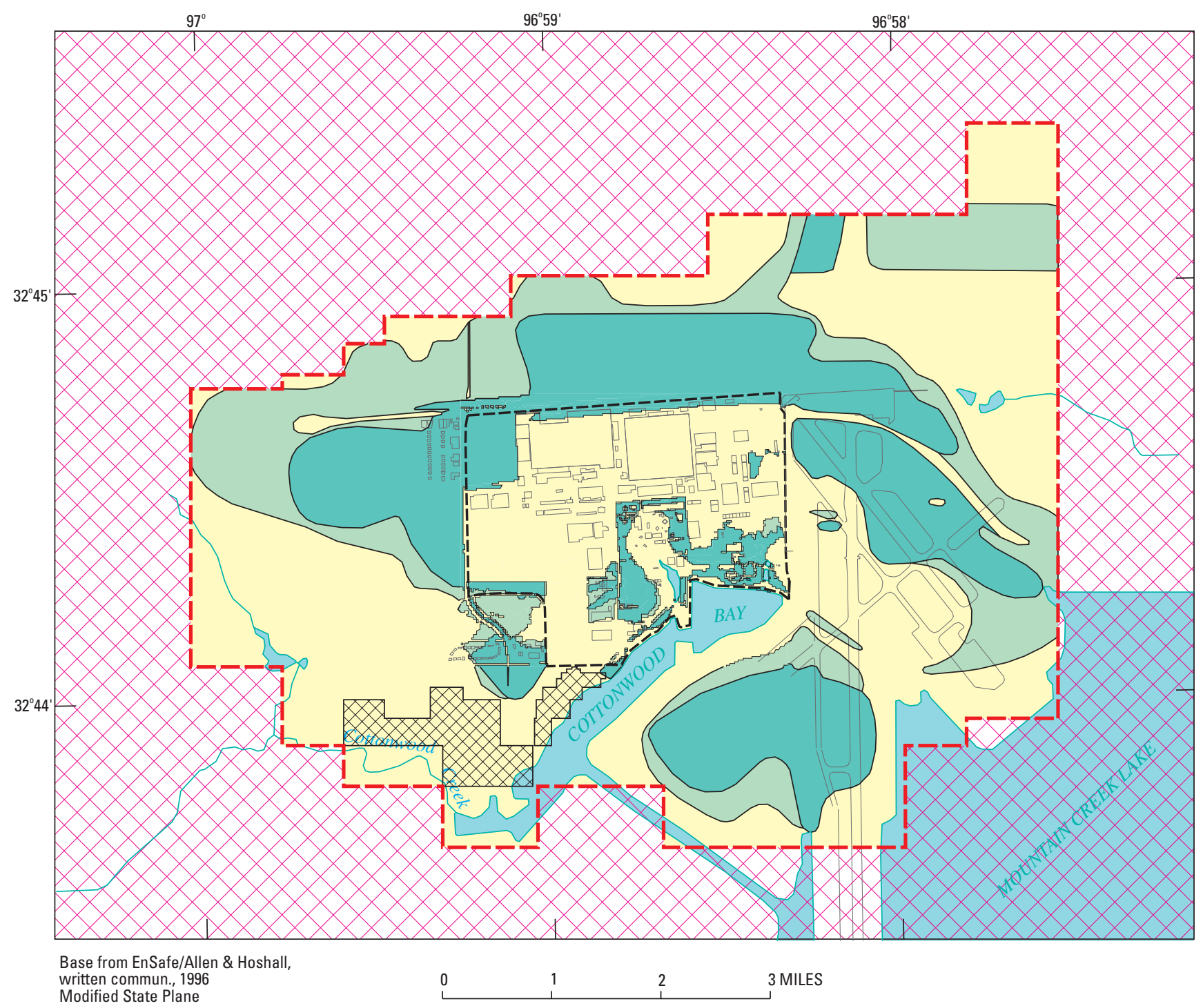

EXPLANATION

Infiltration, in inches per year

$\square$
$\square-0.50$
$\square \quad 0.51-1.50$
$\square \quad 1.51-2.50$

Evapotranspiration, in inches per year

ख $0.01-0.05$

Boundary of Naval Weapons Industrial Reserve Plant

Figure 11. Calibrated distribution of long-term average infiltration to and long-term average evapotranspiration from the alluvial aquifer.

precipitation. In other places, calibration necessitated that infiltration be increased to $2.5 \mathrm{in} / \mathrm{yr}$. The need for more recharge than initially conceptualized on the basis of ground cover is attributed to storm-sewer losses and other plumbing leaks typical of plant operations similar to those at NWIRP (E.L. Kuniansky, U.S. Geological Survey, oral commun., 1998).

Figure 11 shows the final (calibrated) distribution of long-term average infiltration, or recharge resulting primarily from precipitation. The $82.5 \mathrm{gal} / \mathrm{min}$ of 
long-term average infiltration depicted in figure 4 correlates with the $15,910 \mathrm{ft}^{3} / \mathrm{d}$ (table 2) of water that was simulated to infiltrate about $3.42 \mathrm{mi}^{2}$ of active (nonboundary) model area, or an average of $0.73 \mathrm{in} / \mathrm{yr}$. This average rate is much smaller than the conceptualized maximum of $2 \mathrm{in} / \mathrm{yr}$, owing to the large number of impervious, or nearly impervious surfaces within the NWIRP/NAS compound.

\section{Discharge}

\section{Outflow to Drains}

MODFLOW's Drain Package is used to simulate water losses from the aquifer as a result of the west and east drainage lagoons, Cottonwood Creek, and an unnamed, off-site drain (labeled "Eastbound creek," in fig. 4) that discharges eastward toward, and ultimately into, the Mountain Creek swale (figs. 2, 6). Because the Drain Package is designed to only remove water from the aquifer, no water is permitted to flow into the aquifer from a drain. Discharge is simulated at rates proportional to the difference between the simulated water level in the aquifer and a specified drain altitude, provided that the water level is above that altitude. In other words, the rate at which ground water is simulated to discharge from the alluvial aquifer to either drainage lagoon or to any of the off-site creeks depends on the distribution of simulated water levels in time and space.

The simulated rates of discharge (tables 2, 3, and 4) depend also on the simulated conductance of the aquifer-drain interface. The simulated interface conductances (interface area divided by interface thickness multiplied by interface conductivity) range from 5.0 to $250 \mathrm{ft}^{2} / \mathrm{d}$, which equate to drain conductivity values that typically range between about 0.001 to $0.1 \mathrm{ft} / \mathrm{d}$, presumably depending on the relative amounts of clay and (or) silt in the aquifer-drain interface.

\section{Evapotranspiration}

Evapotranspiration (ET) is the process wherein water is discharged from the aquifer as the result of transpiration and (or) evaporation. As simulated, groundwater infiltration represents the net of precipitation minus runoff, minus evapotranspiration - where the residual is usually a ground-water gain. It was recognized during the course of calibration, however, that a net ground-water loss occurs along the northwestern shore of Cottonwood Bay (fig. 11), where evapotranspiration removes water from densely vegetated, low-lying parts of the aquifer that typically receive little or no
Table 2. Simulated long-term average (steady-state) rates of recharge to and discharge from the shallow alluvial aquifer underlying the study area

[In cubic feet per day, rounded to nearest 5 cubic feet per day]

\begin{tabular}{|c|c|}
\hline & $\begin{array}{c}\text { Long-term average } \\
\text { (steady-state) } \\
\text { rate }\end{array}$ \\
\hline \multicolumn{2}{|l|}{ Recharge } \\
\hline Infiltration, including on-site leakage & 15,910 \\
\hline Total & 15,910 \\
\hline \multicolumn{2}{|l|}{ Discharge } \\
\hline Cottonwood Bay & 5,615 \\
\hline West lagoon & 1,200 \\
\hline East lagoon & 1,225 \\
\hline Off-site creeks & 2,300 \\
\hline Mountain Creek Lake & 1,625 \\
\hline Mountain Creek swale & 2,700 \\
\hline Evapotranspiration & 1,245 \\
\hline Total & 15,910 \\
\hline
\end{tabular}

Table 3. Simulated rates of recharge to and discharge from the shallow alluvial aquifer underlying the study area, as of December 31, 1998

[In cubic feet per day, rounded to nearest 5 cubic feet per day]

\begin{tabular}{|c|c|}
\hline & Rate \\
\hline \multicolumn{2}{|l|}{ Recharge } \\
\hline Infiltration, including on-site leakage & 35,475 \\
\hline Cottonwood Bay & 1,325 \\
\hline Change in storage, in & 1,060 \\
\hline Total & 37,860 \\
\hline \multicolumn{2}{|l|}{ Discharge } \\
\hline Cottonwood Bay & 3,815 \\
\hline West lagoon & 810 \\
\hline East lagoon & 465 \\
\hline Off-site creeks & 2,285 \\
\hline Mountain Creek Lake & 1,605 \\
\hline Mountain Creek swale & 2,675 \\
\hline Evapotranspiration & 1,245 \\
\hline Well remediation & 4,225 \\
\hline Trench recovery & 3,155 \\
\hline Change in storage, out & 17,580 \\
\hline Total & 37,860 \\
\hline
\end{tabular}


infiltration. In other words, in these parts of the aquifer, the amount of water lost through evapotranspiration typically is greater than the difference between precipitation and runoff.

MODFLOW's EVT Package is used to remove water from the simulated flow system where evapotranspiration is believed to exceed the difference between precipitation and runoff, thereby avoiding the simulation of negative infiltration rates. Similar to how discharge to drains is simulated, ET (fig. 11) is simulated as proportional to the difference between simulated water levels and a specified depth below which ET losses are assumed negligible. In the USGS model, the evapotranspiration rates are limited to a maximum of $1.35 \times 10^{-5} \mathrm{ft} / \mathrm{d}(0.06 \mathrm{in} / \mathrm{yr})$ at land surface, decreasing linearly to zero at an extinction depth of $5.0 \mathrm{ft}$ below land surface.

\section{Aquifer Properties}

The physical composition of an aquifer determines its hydraulic properties - those properties that control its capacity to transmit and store water. The hydraulic properties of the shallow alluvial aquifer at NWIRP are controlled largely by the size, shape, and sorting of the alluvial sediments, all of which vary areally. The related property, transmissivity, can vary also with time. Because of the strong relation between the physical characteristics of the sediments and the resulting aquifer properties, the initial (uncalibrated) model input data were compiled largely from hydrogeologic sections and lithologic descriptions from Anaya and others (2000), EnSafe/Allen \& Hoshall (1994, 1996-98), as well as from recent aquifer-test data (Jeff James, EnSafe, Inc., written commun., 1998).

\section{Hydraulic Conductivity}

Hydraulic conductivity, a measure of how readily an aquifer transmits water, is used by the model in conjunction with saturated thickness to compute the appropriate distribution of transmissivity. The distribution of hydraulic conductivity depends largely on the nature of the sediments and on the uniformity of the associated mixtures of clay, silt, sand, and (or) gravel. The units of hydraulic conductivity are length (distance) divided by time, the same units as for rate of travel. Thus, the hydraulic conductivity with the ground-water gradient and porosity determine the velocity of a molecule of water (or a conservative chemical constituent) traveling through the shallow alluvial aquifer.
Short-term specific-capacity (pumping rate divided by water-level drawdown in a well) tests at NWIRP provided hydraulic-conductivity estimates ranging from 1 to $35 \mathrm{ft} / \mathrm{d}$, with an average value of about $10 \mathrm{ft} / \mathrm{d}$, from 25 different permeable zones scattered about the site (Jeff James, EnSafe, Inc., written commun., 1997). The results of these specific-capacity tests, in addition to those of subsequent geophysical analyses (Anaya and others, 2000) consistently indicate that the comparatively silty, clay-rich sediments at NWIRP comprise a relatively unproductive aquifer, considering that the hydraulic conductivity of "clean" sand and gravel aquifers typically exceeds $50 \mathrm{ft} / \mathrm{d}$ (Freeze and Cherry, 1979, p. 29).

Early steady-state runs, assuming constant distributions of hydraulic conductivity (ranging from 5 to $15 \mathrm{ft} / \mathrm{d}$ ) produced mixed, mostly inadequate resultsindicating the need for input data that would better reflect the effects of local variations in the physical characteristics of the aquifer. From the early stages of model development, therefore, different distributions of hydraulic-conductivity data were tried as a result of trial-and-error calibration.

The calibrated values of hydraulic conductivity (fig. 12) range from 0.75 to $7.5 \mathrm{ft} / \mathrm{d}$, and average about $4 \mathrm{ft} / \mathrm{d}$. The calibrated values are somewhat smaller than some indicated by the results of specific-capacity tests (Jeff James, EnSafe, Inc., written commun., 1997). Unlike the specific-capacity data, however, the model input data reflect the average hydraulic conductivity of the total saturated thickness, which is likely smaller than that within the typical screened interval of most test-observation wells.

The smaller conductivity values associated with interior parts of the NWIRP/NAS compound (fig. 12) reflect the relatively high clay-content sediments in that area (Anaya and others, 2000). These fine-grained sediments most likely result from overbank, floodplain deposition. The larger conductivity values in the northern part of the area reflect the effect of somewhat coarser grained, comparatively higher velocity deposition. The expanse of largest hydraulic-conductivity values that roughly correlates with the trend of the north-south runway at NAS, possibly results from gravel aggregate or "construction debris" that reportedly was used as fill material to extend the NAS runway during 1949-50 (EnSafe/Allen \& Hoshall, 1997, p. 2-6). 


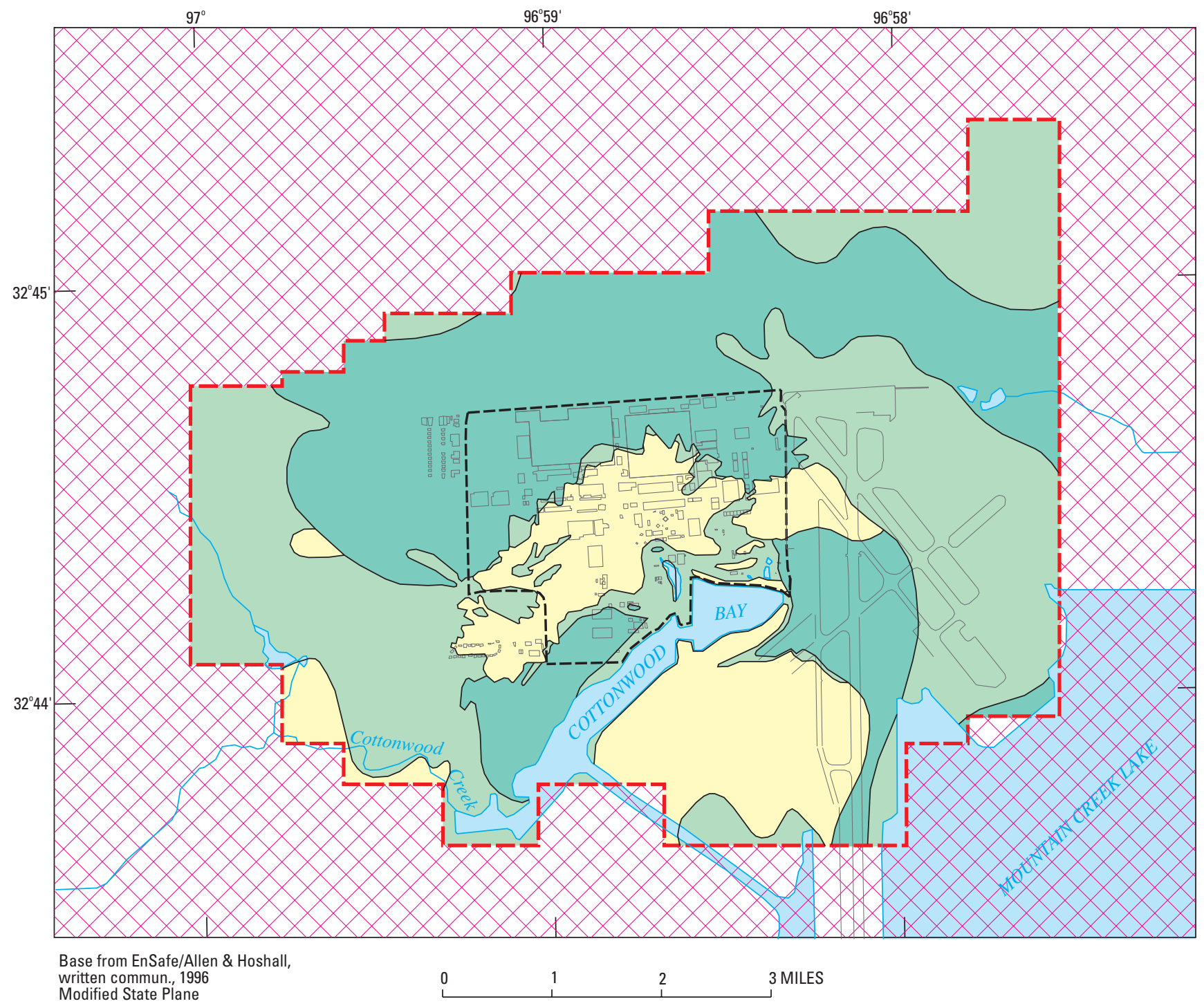

EXPLANATION

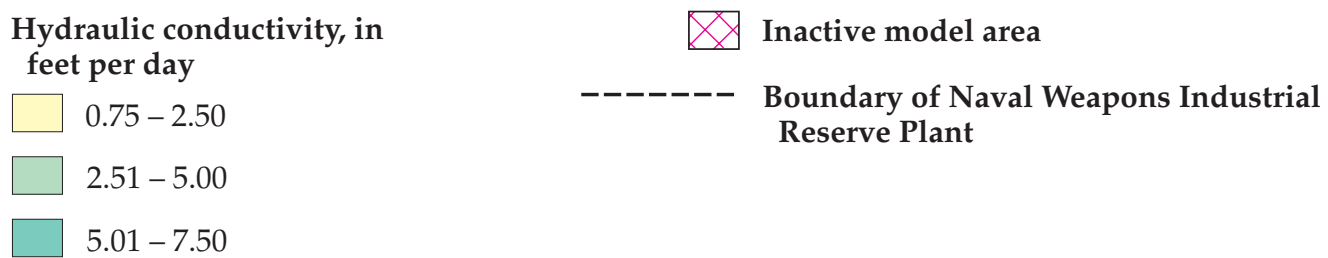

Figure 12. Calibrated distribution of hydraulic conductivity in the alluvial aquifer.

\section{Transmissivity}

The rate at which ground water travels through a cross-sectional area of the aquifer depends on the combined effects of saturated thickness and hydraulic conductivity, the product of which is transmissivity (fig. 13). Saturated thickness (fig. 7) is determined by the distance between the water table, which can vary areally and temporally, and the underlying Eagle Ford Shale. Although hydraulic conductivity - in the aquifer, as well as in the model-is constant with time, transmissivity varies during simulation, as simulated water 


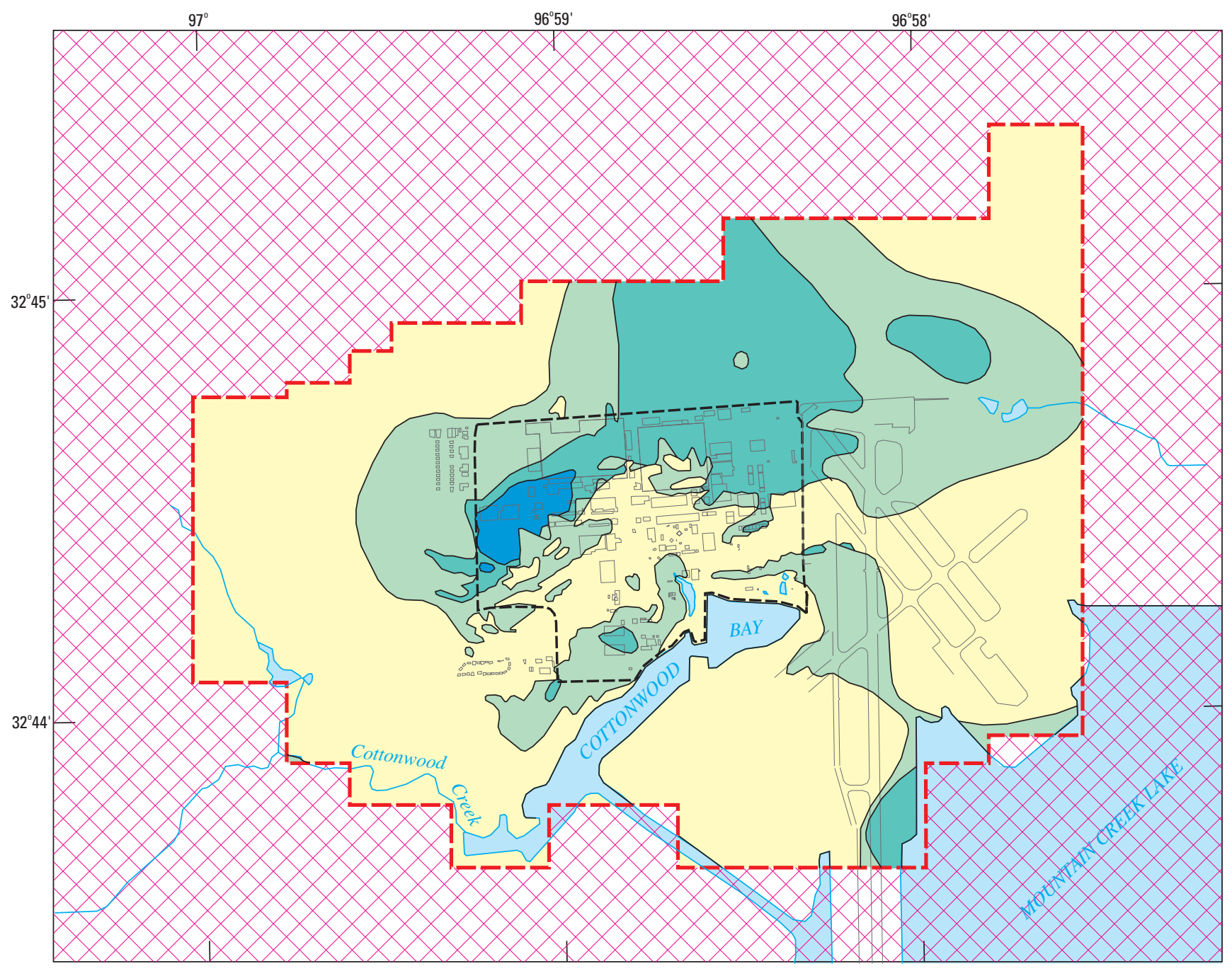

Base from EnSafe/Allen \& Hoshall, written commun., 1996 0 0 12 23 MILES

\section{EXPLANATION}

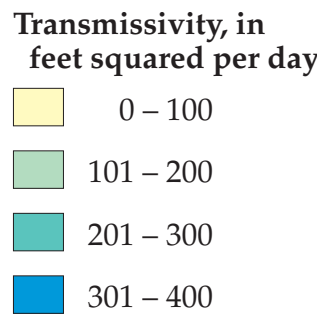

$\varnothing$ Inactive model area

\section{Boundary of Naval Weapons Industrial} Reserve Plant

Figure 13. Calibrated distribution of transmissivity in the alluvial aquifer under natural (unstressed) conditions.

levels rise and fall. All things being equal, the larger the transmissivity, the quicker ground water travels from upgradient recharge areas to downgradient discharge areas of an aquifer.

\section{Specific Yield}

Water-level change in an unconfined aquifer in response to variations in recharge and discharge depends on the magnitude of specific yield. Specific 
yield is related to the degree of sorting and compaction within a particular sediment; generally, the better the sorting and less the compaction, the greater the specific yield. The water-level rise or decline per unit volume of water added to or removed from the aquifer is inversely proportional to the value of specific yield, which typically ranges from about 0.01 to 0.30 (Freeze and Cherry, 1979, p. 61).

Specific yield was the only model input calibrated solely on the basis of simulated transient conditions. The most important water-level data for calibrating the input distribution of specific yield are those reflecting responses to extreme events, such as those caused by either much greater- or much less-than-average rates of precipitation. To obtain water-level data to calibrate the model to more accurately reflect the effects of drought, EnSafe conducted a mass measurement of groundwater levels during late August 1998, near the end of a lengthy period of less-than-average precipitation (fig. 5). The resulting set of water-level data greatly enhanced efforts to calibrate the specific-yield input to the transient model, allowing it to more accurately simulate observed transient conditions.

Figure 14 provides the final, calibrated distribution of specific yield. The pattern of values reflects the combination of having used an areally constant value of 0.1 during most of the calibration effort and fine-tuning late in the process with the help of detailed geophysical interpretation, where available. Accordingly, most of the model values - those outside the area of relatively detailed information - are equal to the overall average value, about 0.08 . In the area where low, intermediate, and high clay-content sediment maps are available for NWIRP (Anaya and others, 2000), the specific-yield values typically are larger or smaller than this average value, depending on the ratio of the thickness of low clay-content sediments to the total thickness of the alluvium at any given finite-difference cell.

The calibrated specific-yield values range from 0.005 to 0.15 and average about 0.08 , reflecting hydraulic conditions ranging between unconfined (Freeze and Cherry, 1979, p. 61) and semiconfined, respectively. Because the model was not designed to differentiate between unconfined and confined conditions during simulation, the simulated distribution of specific yield (fig. 14) remains constant with time.

\section{Steady-State Conditions}

The steady-state model was calibrated as the first of two steps to develop a computer model with which to simulate the effects of contaminant remediation at NWIRP. For the purposes of steady-state calibration, it was assumed that manually contoured water levels (fig. 6) measured in NWIRP and NAS observation wells (pl. 1) during January 1994 (EnSafe/Allen \& Hoshall, 1996) and January 1997 (Jeff James, EnSafe, Inc., written commun., 1997) represented an appropriate map of unstressed (equilibrium) conditions in the aquifer. Owing to the scarcity of data to define, or infer, the "target" water levels, the validity of the steady-state model was not assumed until acceptable transient simulations followed, using water levels simulated with the steady-state model as initial transient conditions.

The steady-state model represents a set of longterm average (essentially unstressed) conditions, a mathematically simple situation, wherein recharge is balanced by discharge and there are no changes in the amount of water in storage. This situation usually is not the case when wells and (or) trenches are removing water from a low-permeability aquifer, such as the alluvial aquifer at NWIRP. A model capable of transient analyses was required to properly assess the effects of water-level and water-budget changes associated with well and trench discharge at NWIRP. However, before a transient model could simulate the effects of remediation, it needed a reasonably accurate distribution of output water levels from the steady-state model.

\section{Water Levels}

The steady-state model of the NWIRP area was calibrated to reproduce long-term average water levels to within +5.1 or $-3.5 \mathrm{ft}$ of those observed or deduced (figs. 15, 16). In statistical terms, the root mean-squared error, sometimes called the "standard error of the estimate," is equal to $1.07 \mathrm{ft}$, with a mean residual of $0.02 \mathrm{ft}$. In other words-assuming a normally distributed disparity between the simulated and inferred (target) water levels - about two-thirds of the active model cells (fig. 3) should provide simulated water levels that differ by no more than about $1 \mathrm{ft}$ from their inferred counterparts. These results, in figures 15 and 16 , appear to justify using this model for steady-state analyses, as well as for obtaining output water levels for initial conditions in subsequent transient simulations. 

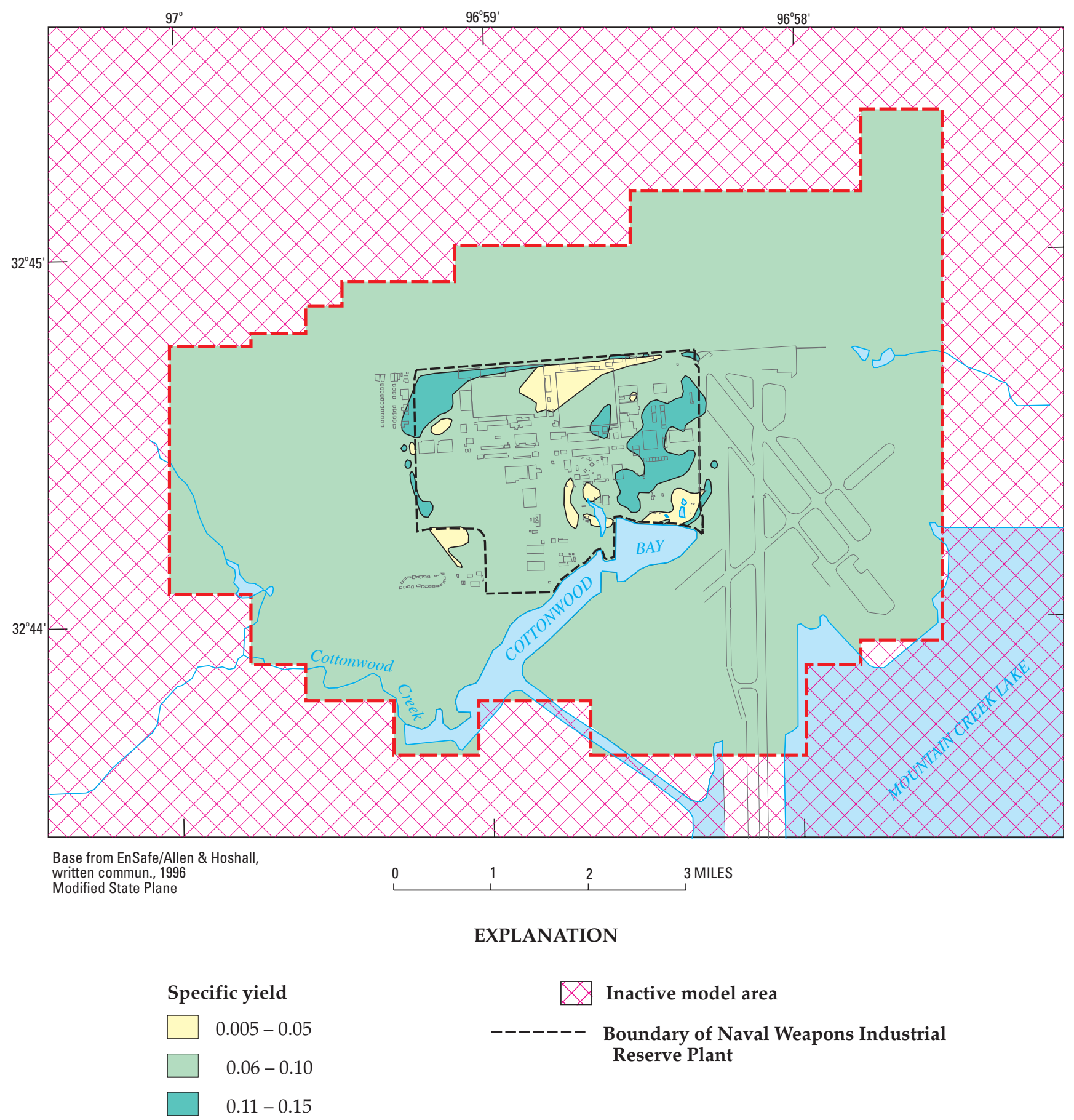

Figure 14. Calibrated distribution of specific yield in the alluvial aquifer.

\section{Water Budget}

By quantifying the long-term average rates at which water enters and leaves the aquifer, the simulated water budget (table 2) defines the relative importance of the different facets of recharge and discharge. Under the predicated conditions of equilibrium between inflow and outflow, the sum of simulated discharges must equal the simulated rate of infiltration, the sole source of recharge to the simulated alluvial aquifer. The "estimated" rates of recharge and discharge, rounded to the 


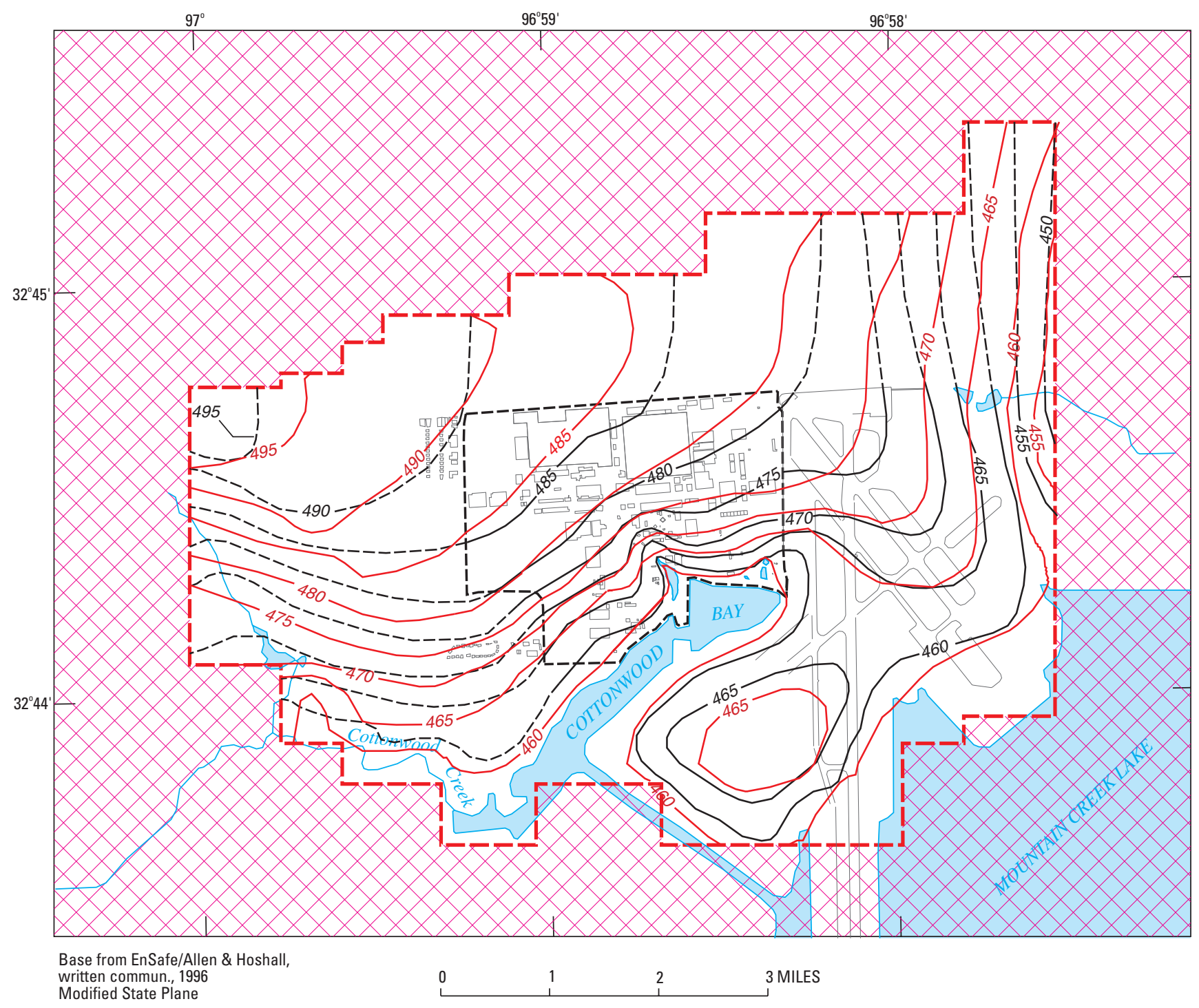

EXPLANATION

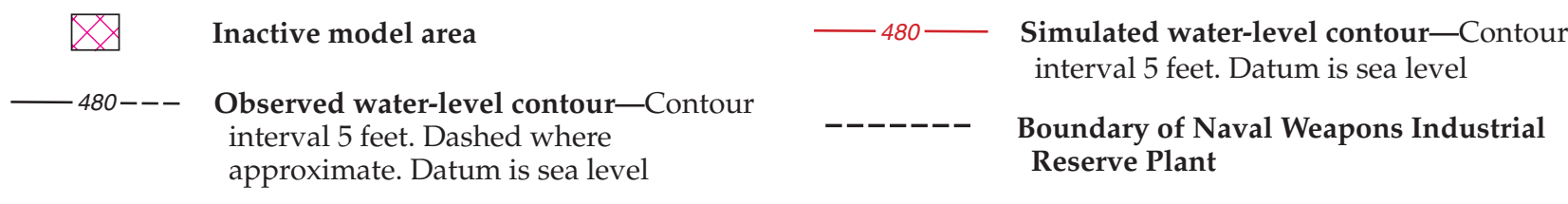

Figure 15. Comparison of observed and simulated long-term average (steady-state) water levels.

nearest $0.5 \mathrm{gal} / \mathrm{min}$, in figure 4 are consistent with those shown more precisely in table 2 , rounded to the nearest $5 \mathrm{ft}^{3} / \mathrm{d}(0.026 \mathrm{gal} / \mathrm{min})$.

The importance of ground-water discharge to Cottonwood Bay can be recognized from table 2. The simulated discharge to Cottonwood Bay $\left(5,615 \mathrm{ft}^{3} / \mathrm{d}\right)$ is more than twice any other component of discharge, and it exceeds the total outflow through all off-site creeks and both drainage lagoons $\left(4,725 \mathrm{ft}^{3} / \mathrm{d}\right)$, in addition to exceeding the combined discharge to Mountain Creek Lake, the Mountain Creek swale, and evapotranspiration $\left(5,570 \mathrm{ft}^{3} / \mathrm{d}\right)$. 


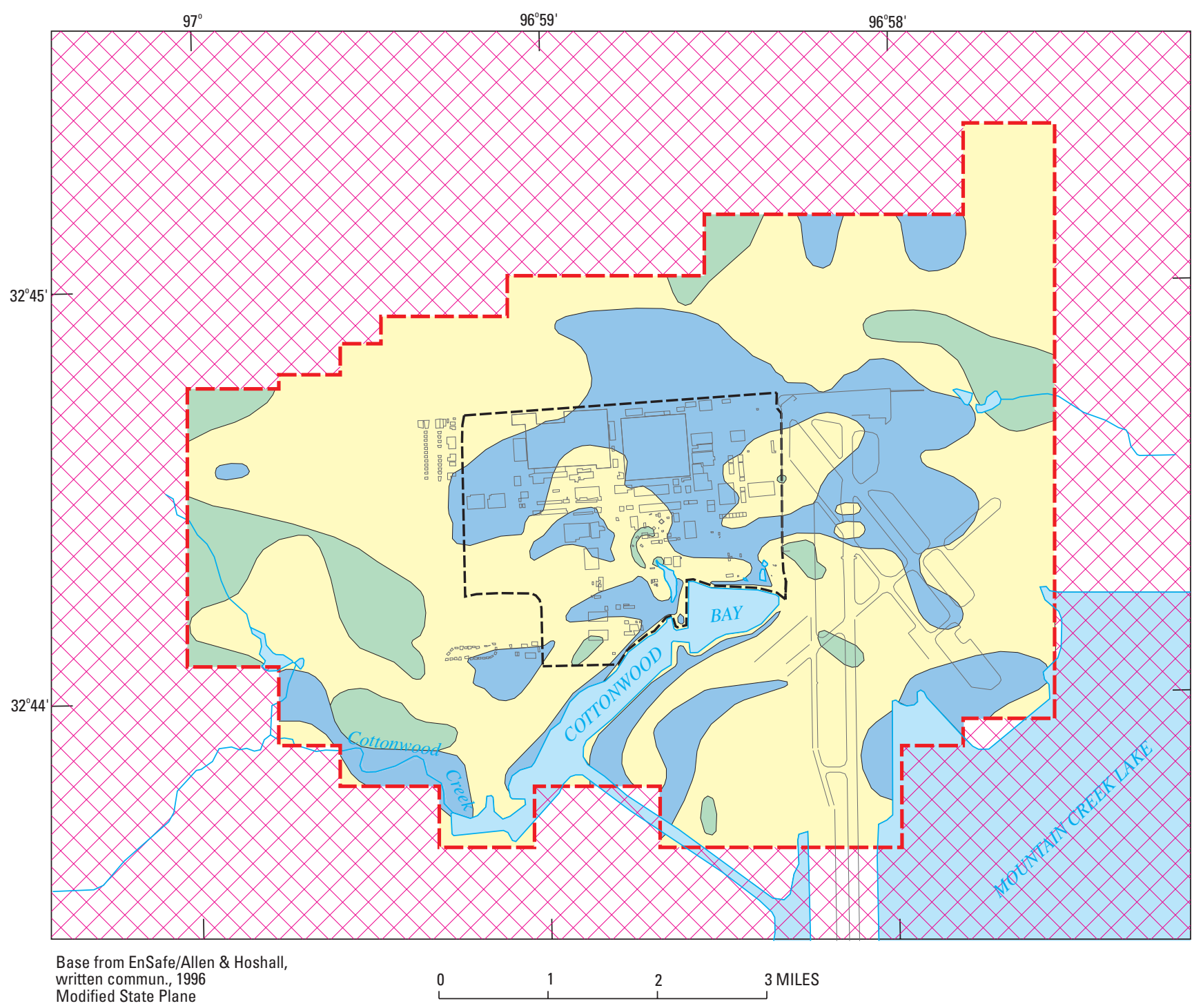

EXPLANATION

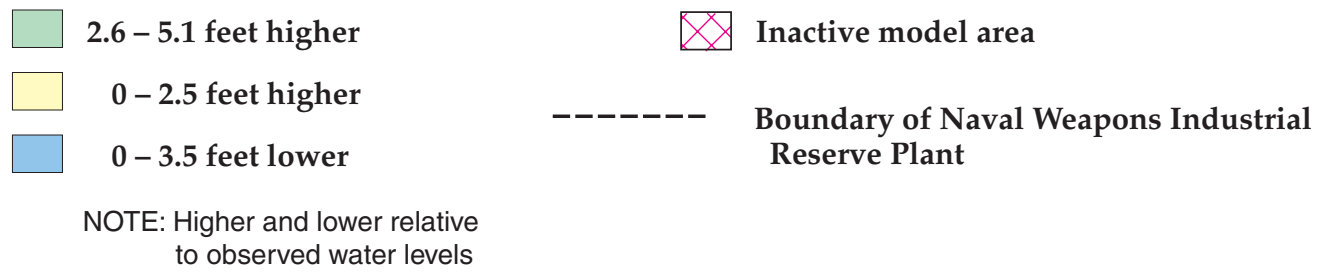

Figure 16. Distribution of differences between observed and simulated long-term average water levels.

\section{Transient Conditions}

In addition to incorporating the areal aspects of ground-water flow, the transient model integrates the time-distribution of hydraulic stresses and aquifer prop- erties to simulate time-dependent conditions. Unlike the comparatively simple steady-state model, the transient model deals with non-steady aquifer stresses and accounts for differences in the volume of ground water in the aquifer (changes in storage) through time. Where 
the steady-state model was calibrated primarily by adjusting the input distributions of infiltration and hydraulic conductivity, transient calibration was dominated by refining the distribution of specific-yield data (fig. 14). Because the success of transient simulation proved to be so dependent on the rates of infiltration and values of hydraulic conductivity, calibration of the transient model evolved into an iterative process of alternating steady-state runs with transient runs, while attempting to make adjustments to the databases of each model that produced mutually satisfactory results.

To ensure that the transient model would simulate hypothetical conditions with reasonable accuracy, it was imperative that it first simulate, with reasonable accuracy, as much hydrologic history as practical. Thus, a calibration period was chosen to provide as many observed responses to as wide a range of hydrologic conditions as possible. The choice of a calibration period was dictated by the availability of precipitation, pool-level, and water-level data (pl. 1, fig. 5) and by the hydraulic stresses of remediation (below). After selecting January 1992-December 1998 as the transient calibration period, a time series of monthly infiltration rates (keyed to precipitation records) and pool-altitude data were constructed to assist calibrating the transient model to approximate the major trends of observed water levels.

Water levels simulated with the calibrated transient model typically track within $\pm 5 \mathrm{ft}$ of water-level fluctuations observed during 1993-98 (fig. 17). The simulated levels are not expected to coincide with the maximum "peaks" and minimum "valleys" of the observed water-level hydrographs, because the model's input of infiltration, pool-altitude, and remediation data is spread over monthly stress periods. Most of the "spikes" in the observed water-level trends result from comparatively short-term, event-driven phenomenasuch as thunderstorms that can release $2.5 \mathrm{in}$. or more of precipitation within 24 hours (Raymond Slade, U.S. Geological Survey, oral commun., 1999). Rather than simulating the short-term (observed) effects of the resulting slug of infiltrated precipitation, the model's monthly timeframe would interpret that $2.5 \mathrm{in}$. $(0.21 \mathrm{ft} / \mathrm{d})$ of precipitation as $0.007 \mathrm{ft} / \mathrm{d}$, when averaged over 30 days. Thus, the simulated response-although valid in consideration of the model's timeframe-is comparatively subtle. Close inspection of figures 5 and 17 and plate 2 indicates good correlation among: (1) the back-to-back months of wetter-than-average precipitation during November and December 1998 (fig. 5); (2) the resulting infiltration (pl. 2); and (3) the corresponding increase in most simulated water-level altitudes during the last quarter of 1998 (fig. 17).

\section{Water Levels}

In addition to simulating major water-level trends through time (fig. 17), the model was used to simulate the areal distribution of water levels for specific dates when observed water levels were available. Water-level measurements made during March 1998 offered such an opportunity (fig. 18). The outcome of comparing observed and simulated water-level contours for March of any given year-a time of comparatively frequent water-level change - would not be as favorable as the results of comparing long-term average water levels to simulated steady-state counterparts (figs. 15, 16). However, the model simulates water levels that are reasonably close to those measured in March 1998-a time of relatively rapid water-level adjustments to relatively rapid changes in the rates of hydrologic activity.

A mass measurement of ground-water levels was conducted by EnSafe during August 1998 in an attempt to record the full or near-maximum effects of drought that had persisted since the previous (March) mass measurement (fig. 5). The results of that effort (Jeff James, EnSafe, Inc., written commun., 1998) were compared to the average water levels in the alluvial aquifer between August and October 1993-97 (fig. 19). The major difference-characterized by an upgradient offset in the contours of August 1998 data-results from the much less-than-average precipitation that occurred during the previous 7 months of 1998. Simulated water levels for this much drier-than-usual set of conditions, once again, provide a reasonable approximation of the observed counterparts (fig. 20).

\section{Water Budget}

Table 3 shows the results of simulating all the known or inferred aquifer conditions-including those resulting from recent remediation activity (figure 8 , table 1) - through the end of 1998. A comparison of tables 2 and 3 indicates important differences in the various elements of the water budget between the longterm average conditions of steady state and those of December 31, 1998.

To explain some differences between the simulated and observed ground-water conditions, the seasonal effects of evaporation might be considered. To perhaps explain why the west lagoon might dry up 


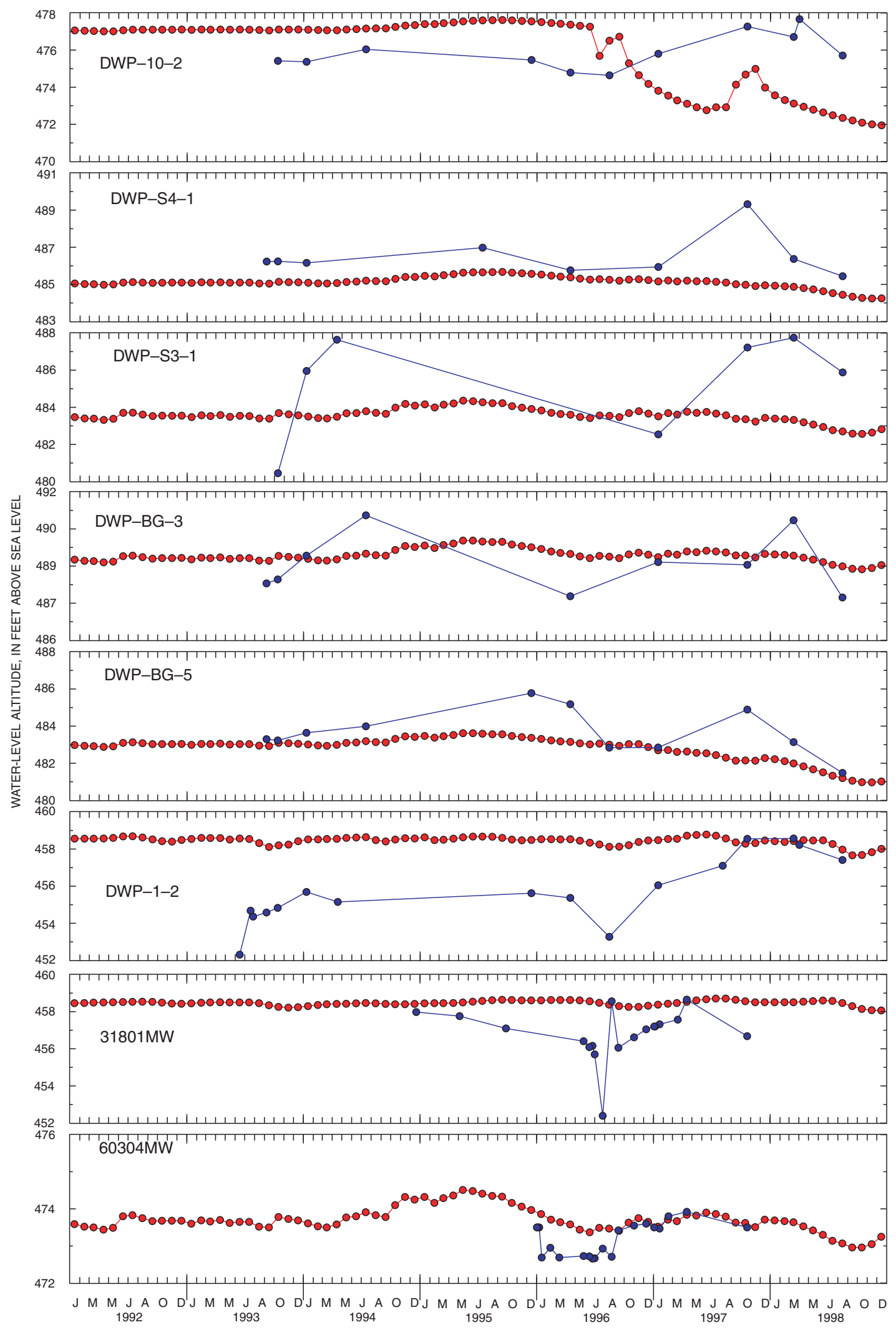

Figure 17. Hydrographs showing comparison of observed (blue) and simulated (red) water levels, 1992-98, for selected wells in the study area. 


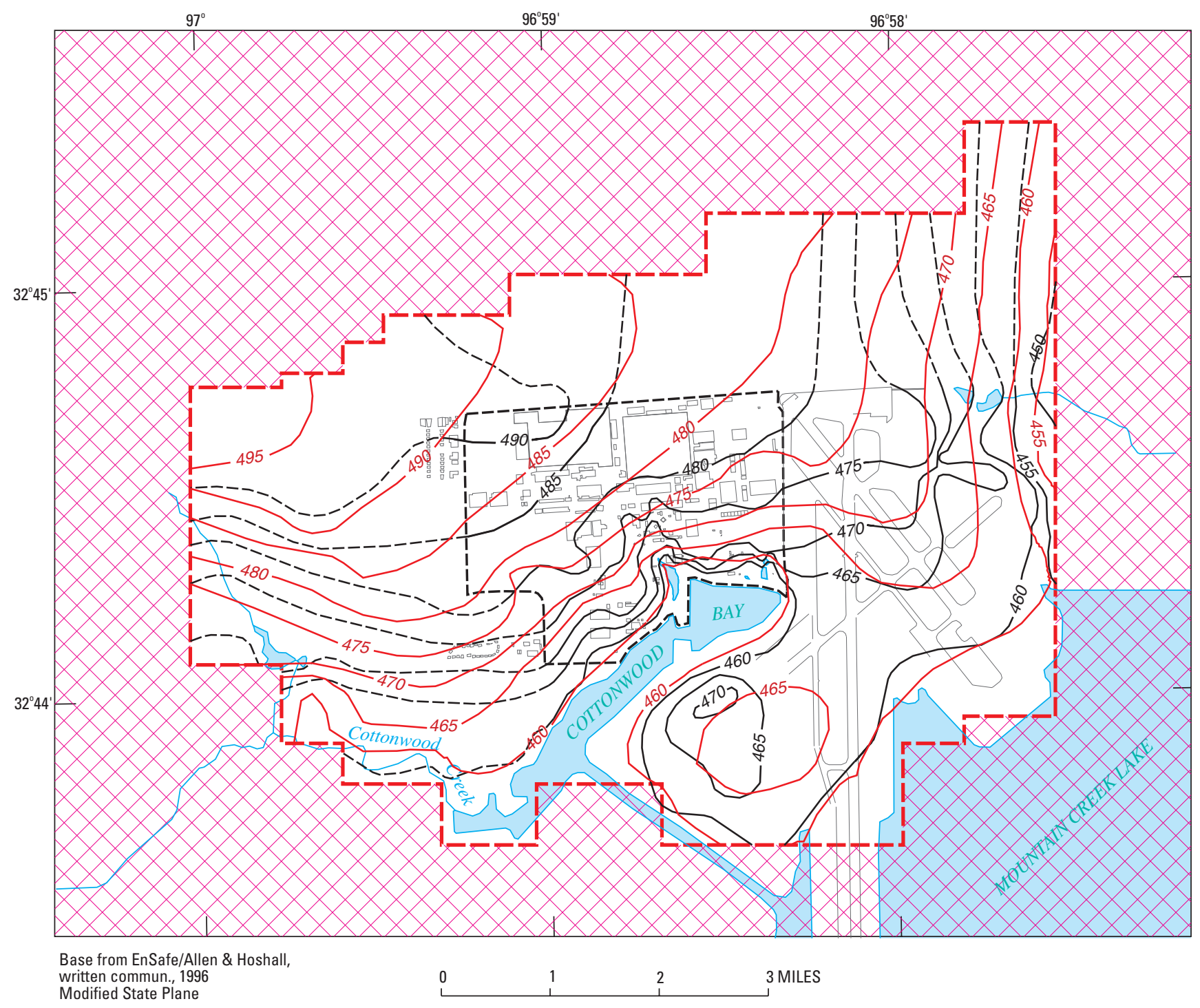

EXPLANATION

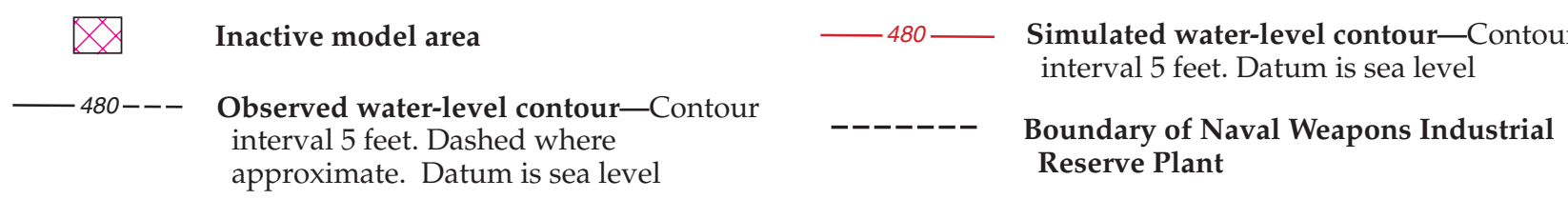

Figure 18. Comparison of observed and simulated March 1998 water levels.

during hot, dry summers, while most ponds that comprise the east lagoon typically remain wet, the effect of different water-surface areas on the volumetric rates of evaporation were obtained from climatological data (Larkin and Bomar, 1983) and used to compile figure 21.
Despite relatively wet conditions during November-December 1998, precipitation during most of this year was much less than average (fig. 5), inducing the west lagoon to dry up during the summer, while the east lagoon remained wet (Jeff James, EnSafe, Inc., written commun., 1998). The simulated conditions for 


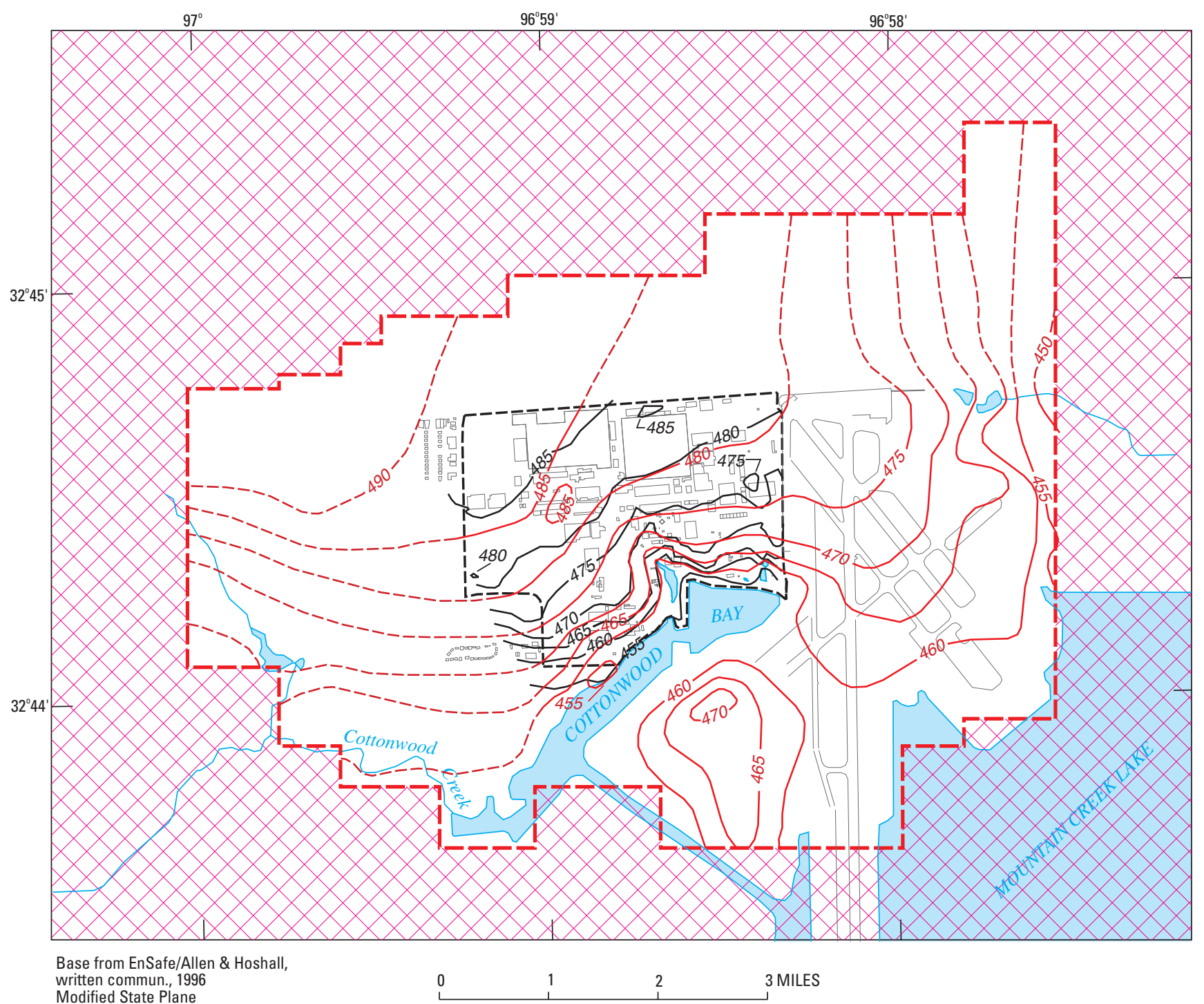

EXPLANATION

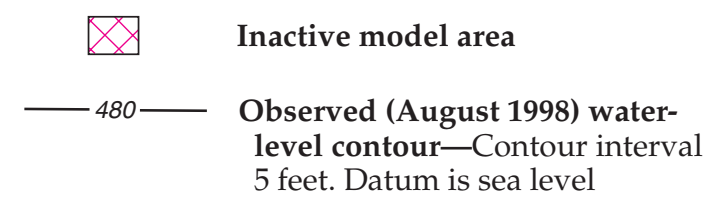

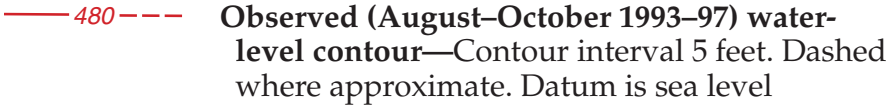

Boundary of Naval Weapons Industrial Reserve Plant

Figure 19. Comparison of observed August 1998 water levels and average of water levels observed between August and October 1993-97.

December 31, 1998 (table 3), which show less discharge to the east lagoon $\left(465 \mathrm{ft}^{3} / \mathrm{d}\right)$ than to the west lagoon $\left(810 \mathrm{ft}^{3} / \mathrm{d}\right)$, might appear inconsistent with this observation, until the effects of evaporation rates per unit surface area are taken into account.
According to figure 21, the average annual rate of evaporation from the west lagoon $\left(1,035 \mathrm{ft}^{3} / \mathrm{d}\right)$ exceeds the simulated ground-water discharge to this lagoon during December 1998 by $225 \mathrm{ft}^{3} / \mathrm{d}$; the average annual rate of evaporation from the east lagoon $\left(405 \mathrm{ft}^{3} / \mathrm{d}\right)$, 


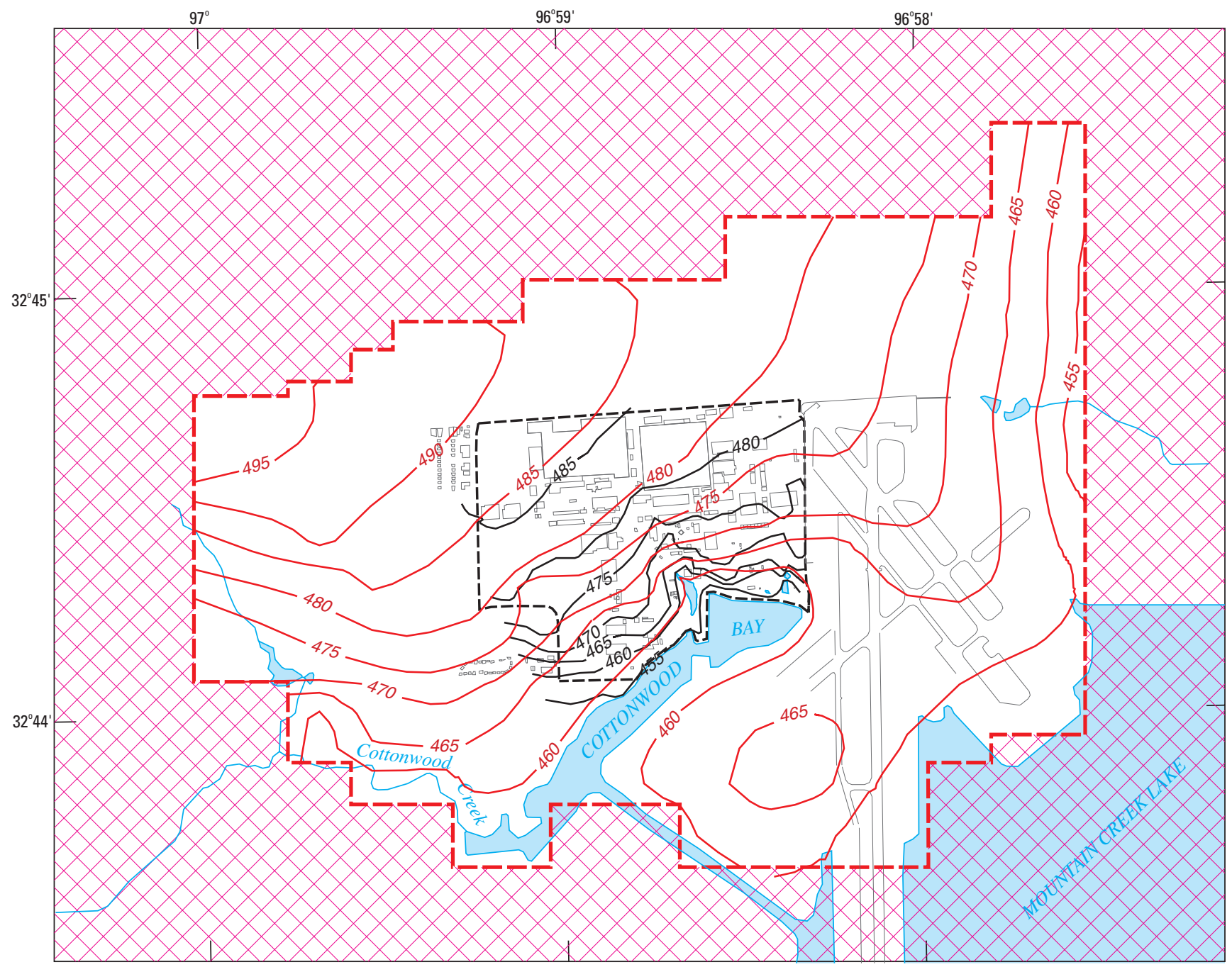

Base from EnSafe/Allen \& Hoshall, written commun., 1996
Modified State Plane $\begin{array}{llll}0 & 1 & 2 & 3 \text { MILES } \\ & 1 & 1 & \text { M }\end{array}$ $\begin{array}{llll}0 & 1 & 2 & 3 \text { MILES } \\ & 1 & 1 & \text { I }\end{array}$ \begin{tabular}{llll}
0 & 1 & 2 & 3 MILES \\
\hline
\end{tabular}

EXPLANATION

Inactive model area
$-480-\begin{aligned} & \text { Observed (August 1998) water-level } \\ & \text { contour-Contour interval } 5 \text { feet. } \\ & \text { Datum is sea level }\end{aligned}$

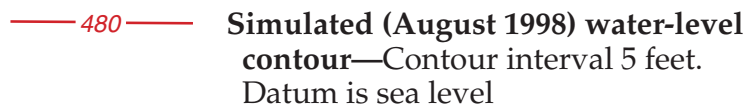

-ーーーーーー Boundary of Naval Weapons Industrial Reserve Plant

Figure 20. Comparison of observed and simulated August 1998 water levels.

however, is $60 \mathrm{ft}^{3} / \mathrm{d}$ less than the simulated discharge into this lagoon during December 1998. The simulated rates of ground-water discharge to the west lagoon during 1998 were exceeded by the average monthly evaporation demand during every month except the 4 latewinter months of January-March and December. In contrast, the simulated discharge to the east lagoon was exceeded by evaporation demands during only the 4 mid-summer months of June-September.

\section{Sensitivity Testing}

There is always some uncertainty associated with the results of model calibration. Sensitivity testing is 


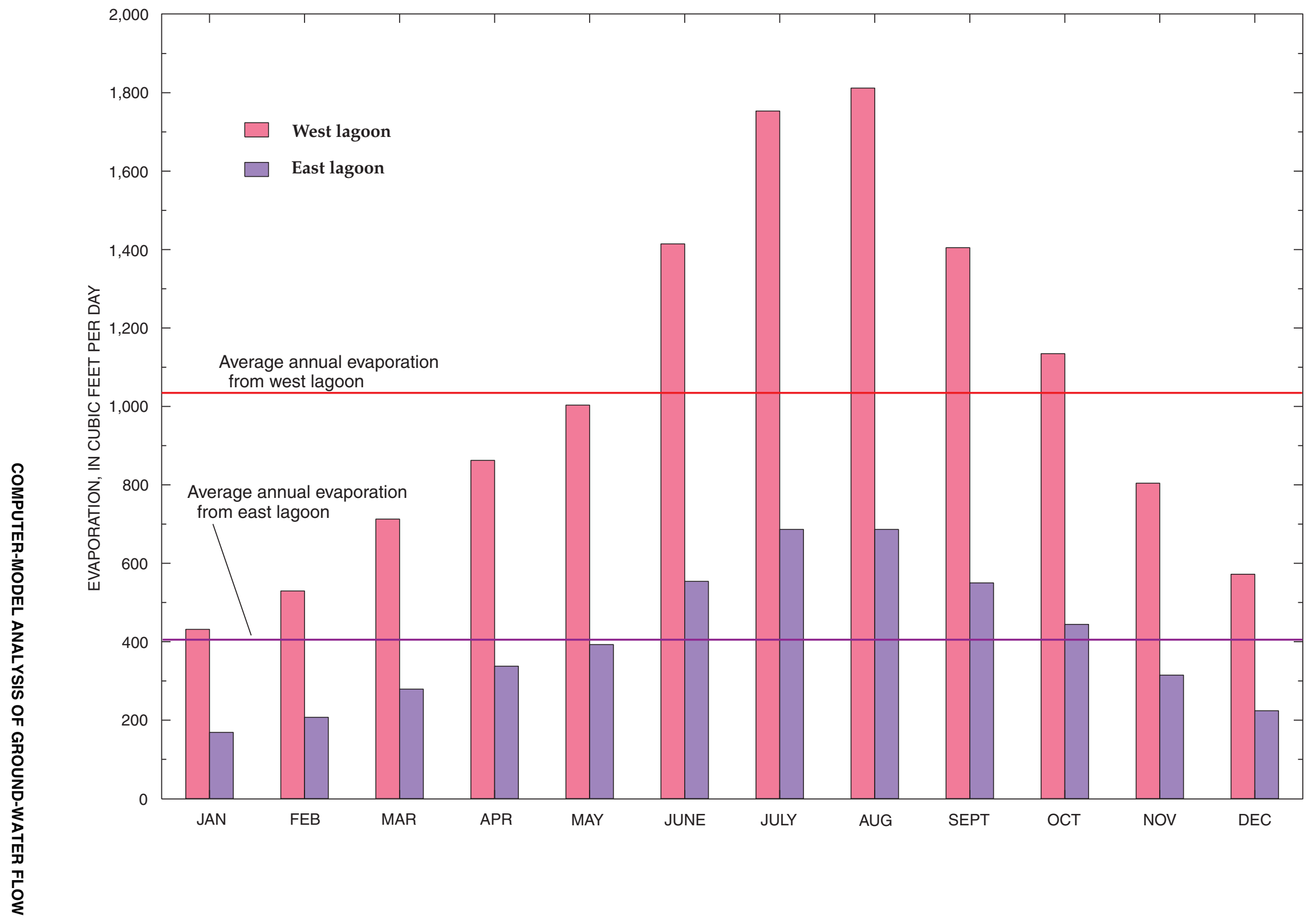

Figure 21. Long-term average monthly and average annual evaporation rates applicable to evaporation losses from the west and east drainage $\omega$ lagoons (adapted from Larkin and Bomar, 1983). 
often used to gauge the importance of possible error in a calibrated database. Accordingly, a series of sensitivity tests were run on input data adjusted during calibration of the USGS model. Each dataset was tested independently of the others to isolate the effects of variation in a single variable from those of the rest.

The steady-state model is most sensitive to variations in the input rates of infiltration and in the input

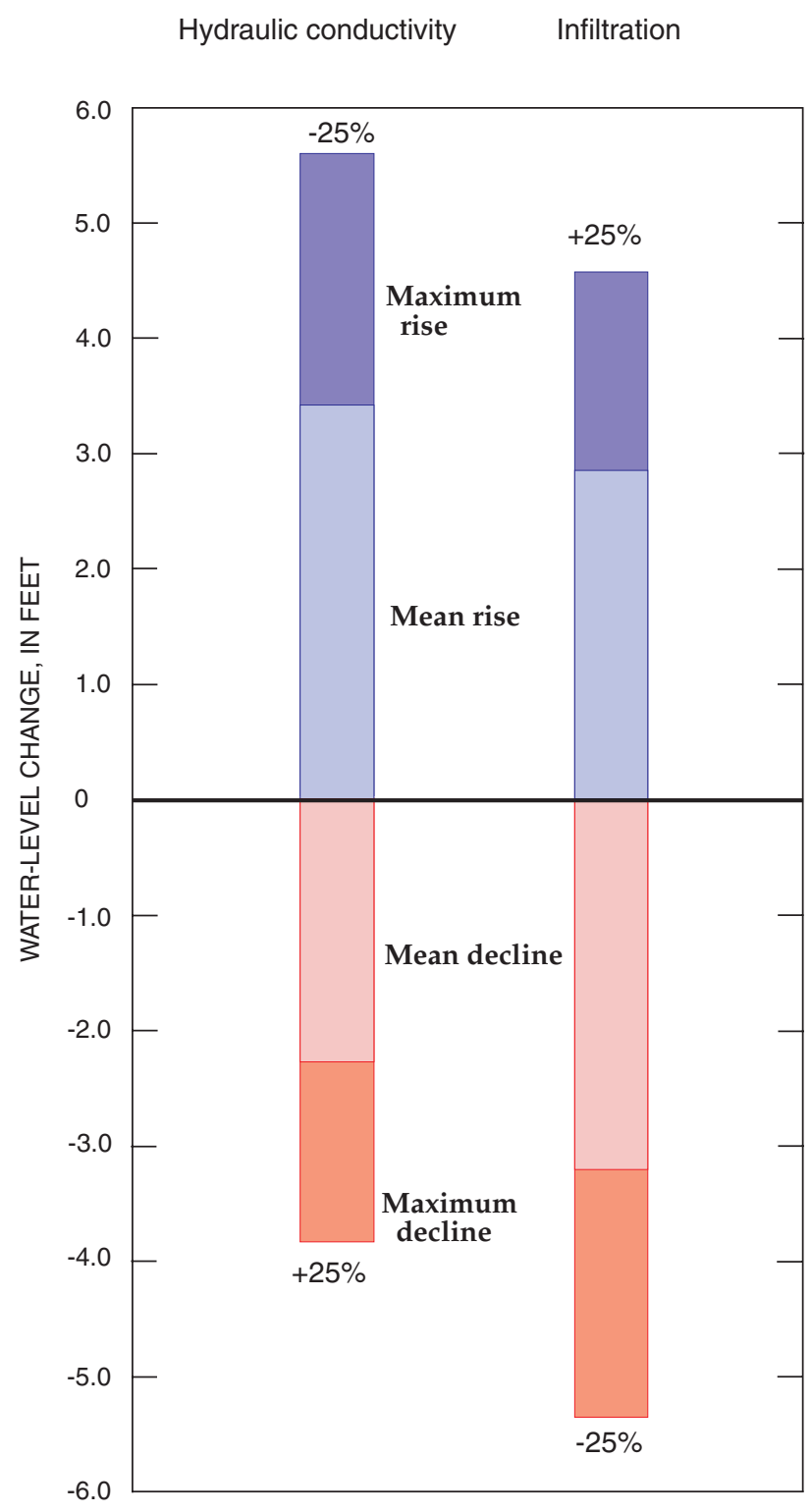

Figure 22. Responses of simulated long-term average water levels to 25-percent increases and 25-percent decreases in the calibrated values of hydraulic conductivity and the calibrated rates of infiltration in the steady-state model. values of hydraulic conductivity. The effects of infiltration and hydraulic conductivity are inversely proportional. An increase in the rate of infiltration adds water to the aquifer; therefore, water levels rise. A decrease in the value of hydraulic conductivity impedes flow, also causing water levels to rise. An increase in hydraulic conductivity flattens the ground-water gradient, so water levels drop. A decrease in infiltration also flattens the gradient, causing water-level decline.

In the steady-state model, a 25-percent overall increase in the calibrated rates of infiltration causes an average head rise of about $2.8 \mathrm{ft}$ in the simulated water levels (fig. 22). A 25-percent decrease in infiltration rates produces about $3.2 \mathrm{ft}$ average decline. Conversely, a 25-percent increase in the calibrated values of hydraulic conductivity produces an average head decline of about $2.3 \mathrm{ft}$, whereas a 25-percent decrease provides an average head rise of about $3.4 \mathrm{ft}$. Maximum waterlevel changes of nearly $6 \mathrm{ft}$ (in opposite directions) are achieved by a 25-percent decrease in either hydraulicconductivity values or infiltration rates. Likewise, maximum water-level changes of between nearly 4 and about $5 \mathrm{ft}$ result from increasing either hydraulicconductivity values or infiltration rates by 25 percent.

Simulations were made with the transient model to ascertain the water-level responses to changes in the values of the key input parameter, specific yield. Because specific yield was the only parameter adjusted during transient calibration, it was the only transient parameter tested for sensitivity. Figure 23 shows the simulated responses to independently raising and lowering specific-yield values to 50 percent more than and to 50 percent less than the calibrated values. The results indicate that the simulated water levels are more sensitive to decreases in specific yield than to comparable increases. The maximum simulated water-level differences that result from 50-percent variations in specific yield range from about $0.5 \mathrm{ft}$ for well DWP-1-2 to about $1.5 \mathrm{ft}$ for well DWP-10-2. These differences are small, compared to the simulated responses to 25-percent variations in the values of hydraulic conductivity and rates of infiltration in the steady-state model (fig. 22).

The differences among the hydrographs in figure 23 (plotted for same wells as in fig. 17) are indications of the range in simulated water levels associated with what is believed to be the maximum possibility for error in the input values of specific yield. The pattern of disparity in figure 23 indicates that the calibrated values of specific yield provide results that, for the most part, 


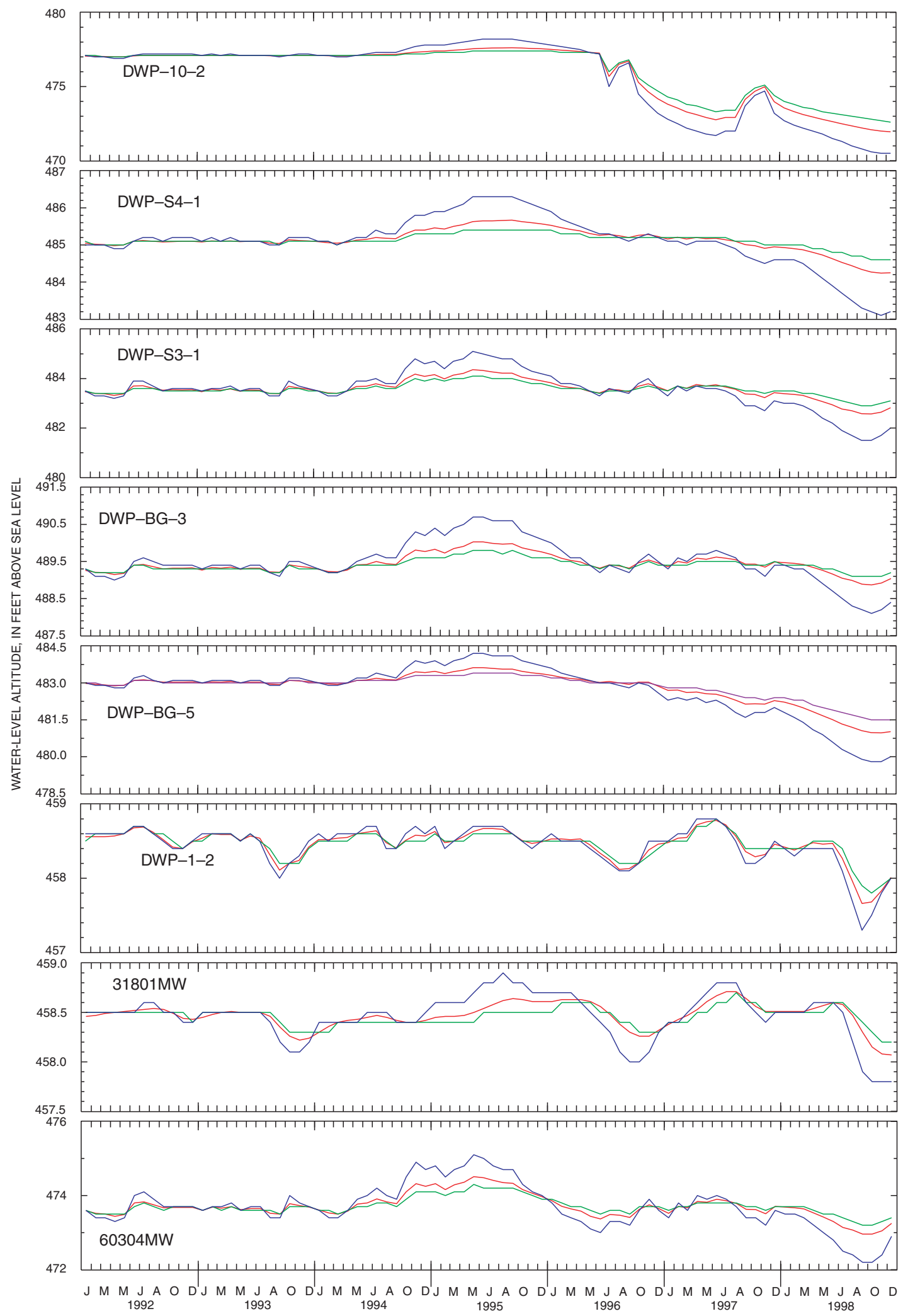

Figure 23. Hydrographs showing responses of simulated water levels in selected observation wells to 50-percent increases (blue) and to 50-percent decreases (green) in the calibrated values (red) of specific yield in the transient model. 


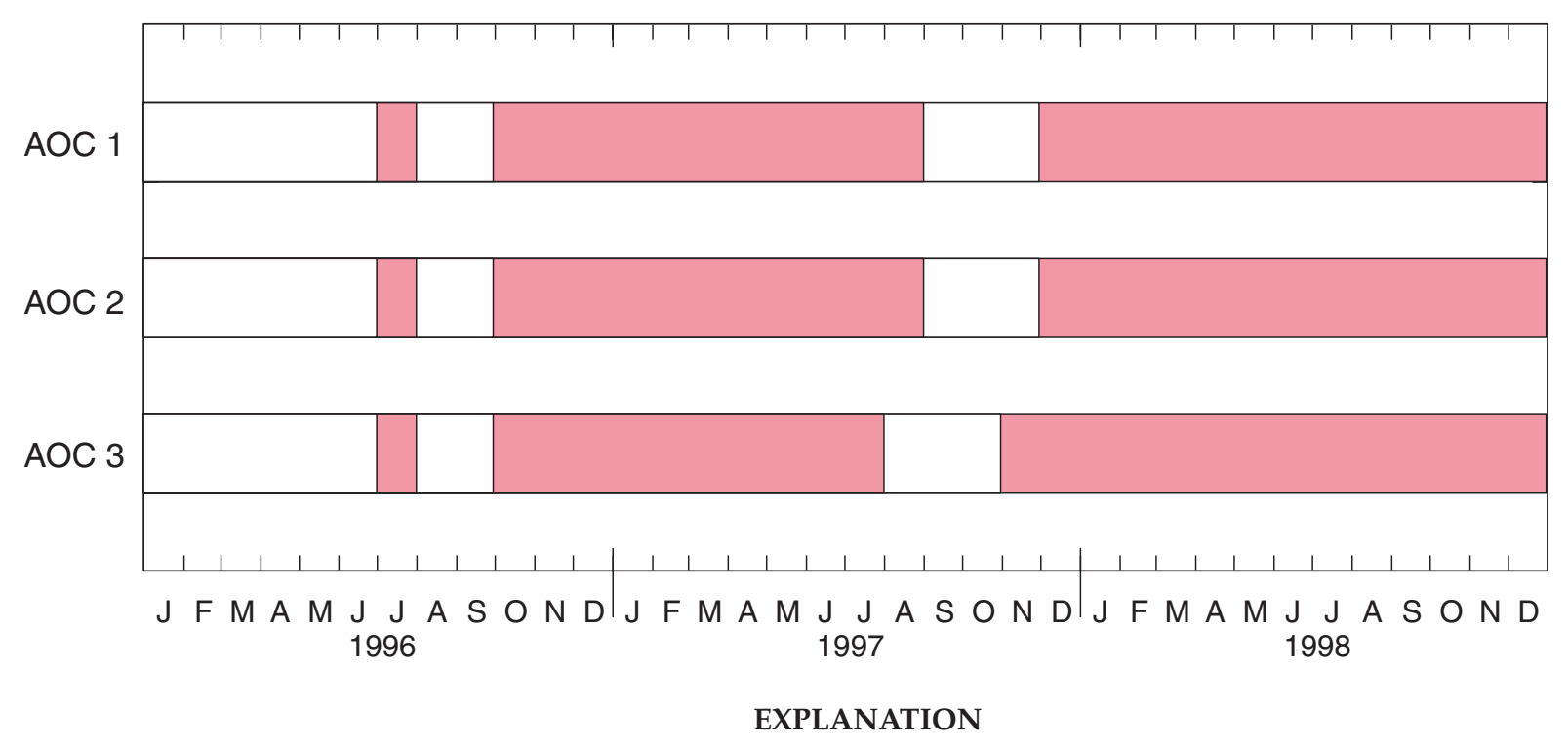

Inactive (sump pump off)

Active

Figure 24. Schedule of remediation activities during January 1996-December 1998 at Areas of Concern (AOC) 1, 2 , and 3.

are well within the range of those provided by the extreme possibilities. Compared to the hydrographs of observed water levels (fig. 17), the simulated responses to 50-percent departures from the calibrated values of specific yield (fig. 23) indicate that the capability of the model to simulate actual conditions generally deteriorates as those departures increase.

\section{SIMULATED EFFECTS OF CONTAMINANT REMEDIATION}

The calibrated transient model was used to simulate the effects of contaminant remediation at AOCs 1, 2, and 3 (table 1). Stabilization systems (fig. 8) were installed at these AOCs to minimize the possibility of TCE or other VOCs to migrate off-site and (or) into surface-water bodies (EnSafe/Allen \& Hoshall, 1994, p. 3-1). Although the remediation systems (consisting of two well fields and one recovery trench) have been in place since July 1996, they did not operate on a moreor-less continuous basis until at least January 1997. Even since January 1997, there have been a few intervals of downtime-some scheduled, some unforeseen (EnSafe/Allen \& Hoshall, 1997 and 1998).

The results of MODFLOW and MODPATH simulations have been used to evaluate the hydrologic effects of remediation activity at NWIRP. Objectives of these simulations have included delineations of: (1) capture zones resulting from well withdrawals at AOCs 1 and 2 and discharge to the recovery trench at AOC 3; (2) differences between pre- and postremediation water levels and (or) water budgets; and (3) flow rates and flowlines of water removed through the trench at AOC 3. Summaries of these delineations are provided below.

Except for the "stressed" steady-state simulations used for all particle-tracking analyses, the simulations proceeded through 84 monthly stress periods (January 1992-December 1998). Infiltration rates were updated during the simulation according to the product of longterm average infiltration rate (fig. 11) and the monthly percentage of long-term average precipitation (fig. 5). Monthly Cottonwood Bay levels tracked the historic pool-level data (fig. 5).

All well and trench activity was simulated, as best the available information could be assimilated, according to NWIRP hazardous waste management records. The schedule used to activate and deactivate the remediation systems in the model (fig. 24) was generalized from operational logs maintained by Morrison Knudsen Corporation and reported in stabilization performance 


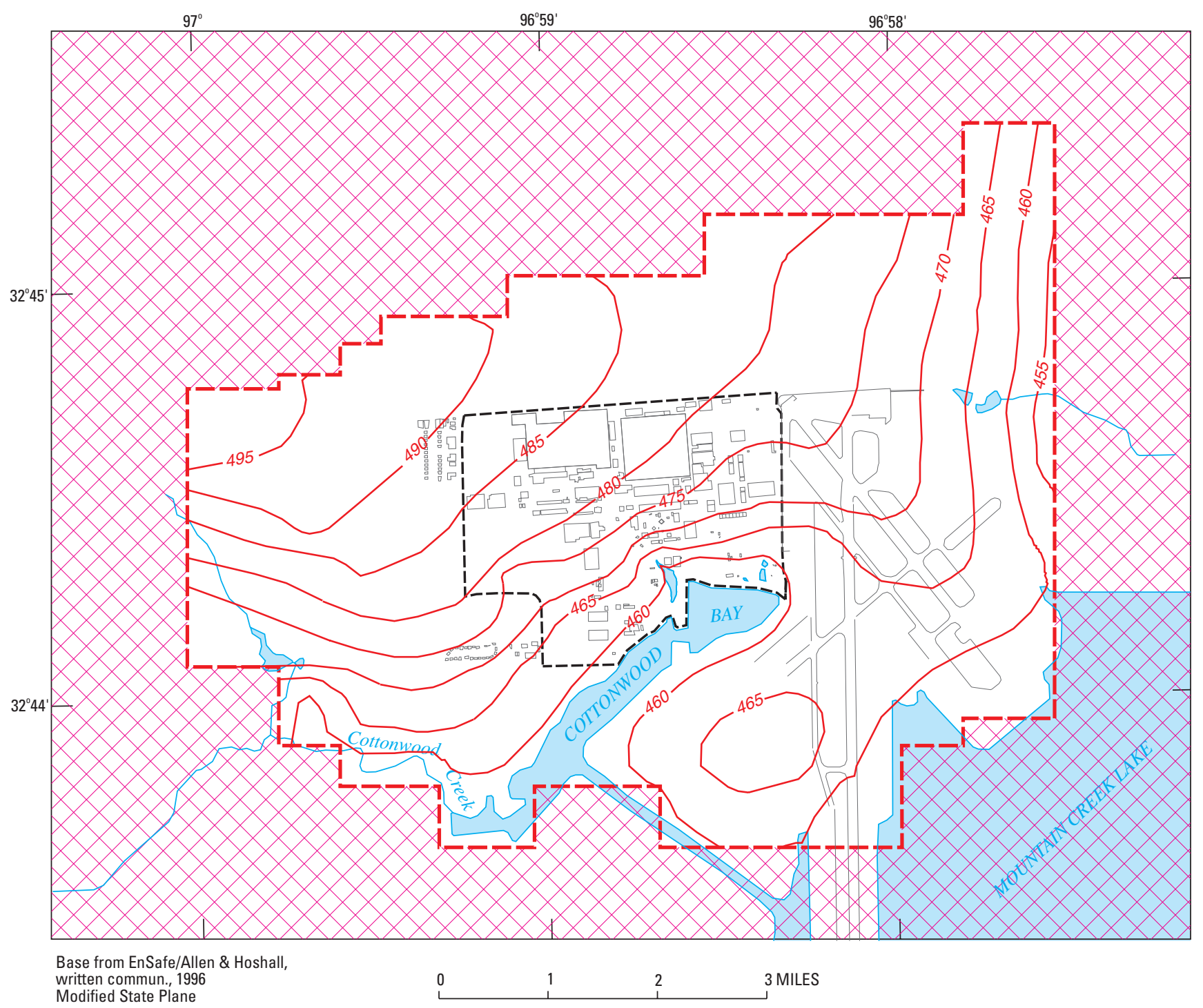

EXPLANATION

Inactive model area
$-480-\begin{gathered}\text { Simulated water-level contour-Contour } \\ \text { interval } 5 \text { feet. Datum is sea level }\end{gathered}$

Boundary of Naval Weapons Industrial Reserve Plant

Figure 25. Simulated distribution of water levels, as of December 31,1998 , following remediation during July 1996-December 1998 at Areas of Concern 1, 2, and 3.

evaluation reports prepared by EnSafe/Allen \& Hoshall (1997 and 1998). The recovery trench at AOC 3 (continuously evacuated with a sump pump) was simulated as a hydraulic drain, with conductivity varying areally between 1.5 and $9.75 \mathrm{ft} / \mathrm{d}$ and altitudes ranging from 0 to $5.0 \mathrm{ft}$ above the top of the Eagle Ford Shale.

\section{Withdrawals at Areas of Concern 1, 2, and 3}

Figure 25 provides the distribution of water levels associated with the simulated water budget in table 3 . Figure 26 shows the distribution of drawdown associated with the contours in figure 25 and with the water 


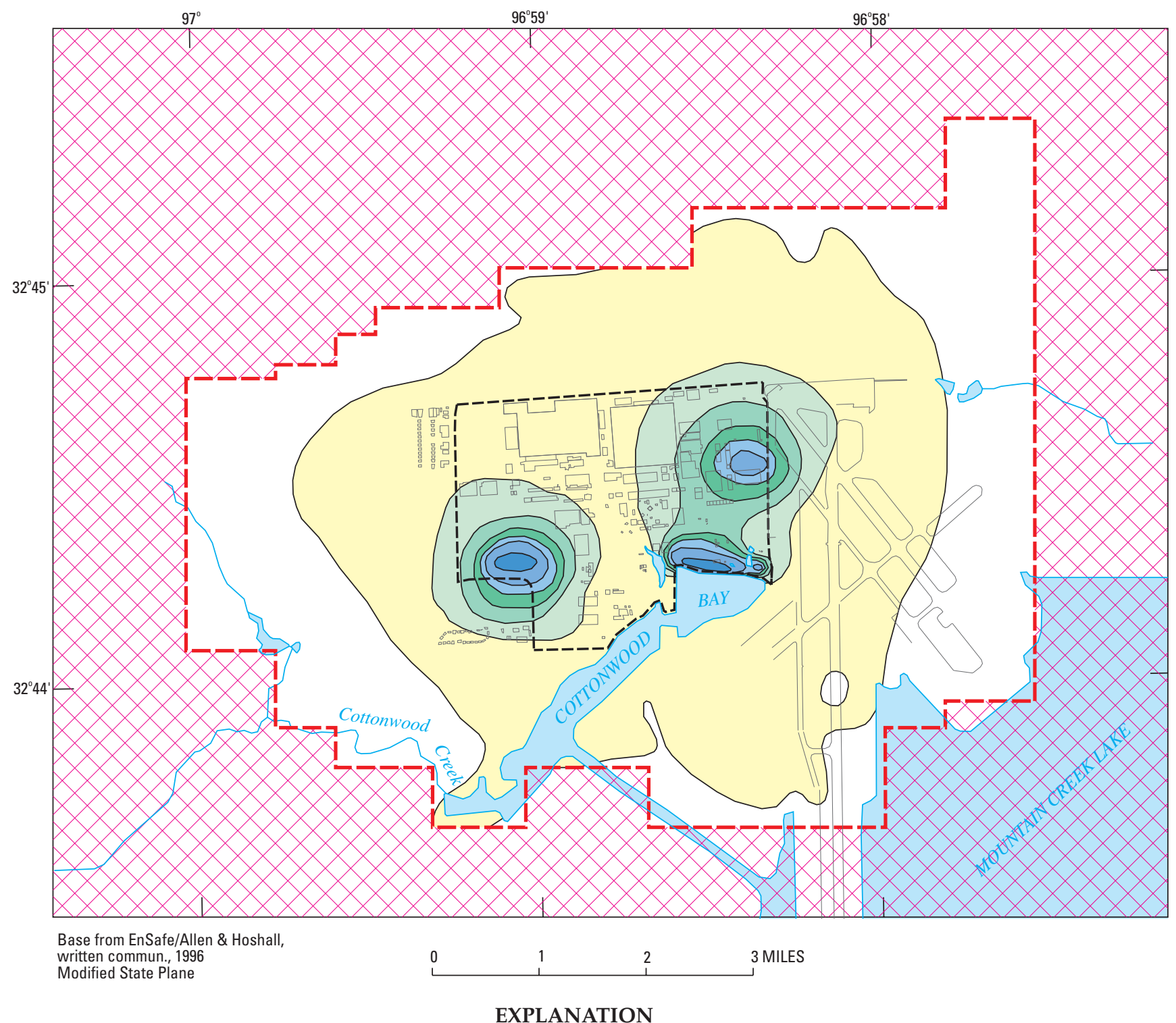

Water-level drawdown, in feet

Less than 0.10

$0.10-1.00$

Inactive model area

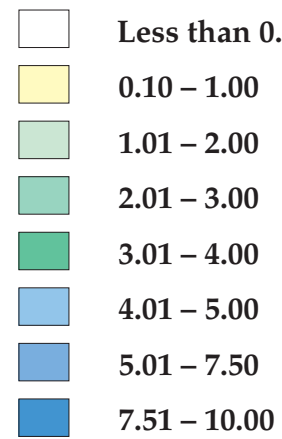

NOTE: Drawdown is relative to long-term average (steady-state) conditions

Figure 26. Simulated distribution of water-level drawdown, as of December 31, 1998, following remediation during July 1996-December 1998 at Areas of Concern 1, 2, and 3. 
budget in table 3 . Tables $4 \mathrm{a}$ and $4 \mathrm{~b}$ provide a summary of how the rates of recharge and discharge have adjusted in response to the discharge of ground water through the remediation wells and recovery trench. Data in these illustrations and table result from simulations of actual conditions of infiltration and pool levels (as best they could be interpreted from data in fig. 5 and translated into the model) through December 31, 1998.

Table 4a indicates that, as of December 31, 1998, the remediation systems at NWIRP were removing a total of $7,375 \mathrm{ft}^{3} / \mathrm{d}$ of water from the alluvial aquifer.

Table $4 \mathrm{~b}$ indicates that the amount of this total coming directly from aquifer storage (producing the drawdown in figure 26) equaled $3,050 \mathrm{ft}^{3} / \mathrm{d}$. Compared to preremediation conditions, another $1,325 \mathrm{ft}^{3} / \mathrm{d}$ was induced to flow from Cottonwood Bay into the aquifer as a result of localized reversals in the hydraulic gradient. This is in addition to $1,800 \mathrm{ft}^{3} / \mathrm{d}$ of ground water that-relative to pre-remediation conditions-no longer discharged to Cottonwood Bay, owing to the reduction in aquifer-tobay gradients. Table $4 \mathrm{~b}$ indicates that $1,200 \mathrm{ft}^{3} / \mathrm{d}$ (of the total $7,375 \mathrm{ft}^{3} / \mathrm{d}$ withdrawn through remediation) was from decreased discharge to the west lagoon, east lagoon, Mountain Creek Lake, and Mountain Creek swale, owing to the relatively depressed ground-water levels on December 31, 1998.

MODPATH, a particle-tracking program, was used in conjunction with output from MODFLOW to trace imaginary particles of water backward from AOCs 1, 2, and 3 to ascertain the areal extent of actual as well as potential remediation activity. Particle movement is dependent on pore velocity, and these velocities are greatly affected by porosity. Steady-state ground-water gradients and flow rates obtained with MODFLOW were applied to MODPATH simulations to delineate capture zones, or areas of remediation withdrawals, assuming an aquifer porosity of 0.15 . The results (fig. 27) indicate areas of the alluvial aquifer from which ground water has been removed during the last 2.5 years (July 1996-December 1998), as well as areas from which ground water would be removed during the next 2.5 years (January 1999-June 2001).

Although the capture zones displayed in figure 27 share similarities with the drawdown patterns in figure 26, the particle-tracking flowlines are manifestations solely of the simulated remediation activity. This is because the particle-tracking simulations are superimposed on long-term average conditions of infiltration and pool levels. The drawdowns depicted in figure 26 also reflect the additional effects of drought and comparatively depressed Cottonwood Bay pool levels (fig. 5). Another factor that might contribute to differences between the drawdowns (fig. 26) and capture zones (fig. 27) is that the aquifer porosity assumed for the particle-tracking analyses is estimated. If the actual porosities were, in fact, less than that assumed here (0.15), then the flowlines in figure 27 would extend farther from the wells and recovery trench than those currently depicted.

\section{Withdrawals at Area of Concern 3}

Figures 28-30 show the results of simulations designed to evaluate the rates of water removed through the recovery trench at AOC 3 . Figure 28 shows the simulated distribution of ground-water discharge that would occur without a trench, across the present

Table 4a. Simulated rates of ground-water discharge from the shallow alluvial aquifer underlying the study area, as of December 31, 1998, following remediation during July 1996-December 1998 at Areas of Concern 1,2 , and 3

[In cubic feet per day, rounded to nearest 25 cubic feet per day]

\begin{tabular}{|c|c|}
\hline Location of water removed & Rate \\
\hline Area of Concern 1 & 2,150 \\
\hline Area of Concern 2 & 2,075 \\
\hline Area of Concern 3 & 3,150 \\
\hline Total & 7,375 \\
\hline
\end{tabular}

Table 4b. Simulated effects on rates of recharge to and discharge from the shallow alluvial aquifer underlying the study area, as of December 31, 1998, following remediation during July 1996-December 1998 at Areas of Concern 1, 2, and 3

[In cubic feet per day, rounded to nearest 25 cubic feet per day]

\begin{tabular}{|c|c|}
\hline Source of water removed ${ }^{1}$ & Rate \\
\hline From change in storage, out & 3,050 \\
\hline More from Cottonwood Bay & 1,325 \\
\hline Less to Cottonwood Bay & 1,800 \\
\hline Less to Mountain Creek Lake and swale & 50 \\
\hline Less to west lagoon & 400 \\
\hline Less to east lagoon & 750 \\
\hline Total & 7,375 \\
\hline
\end{tabular}

1 "More" and "less" are relative to long-term average (pre-remediation) conditions. 


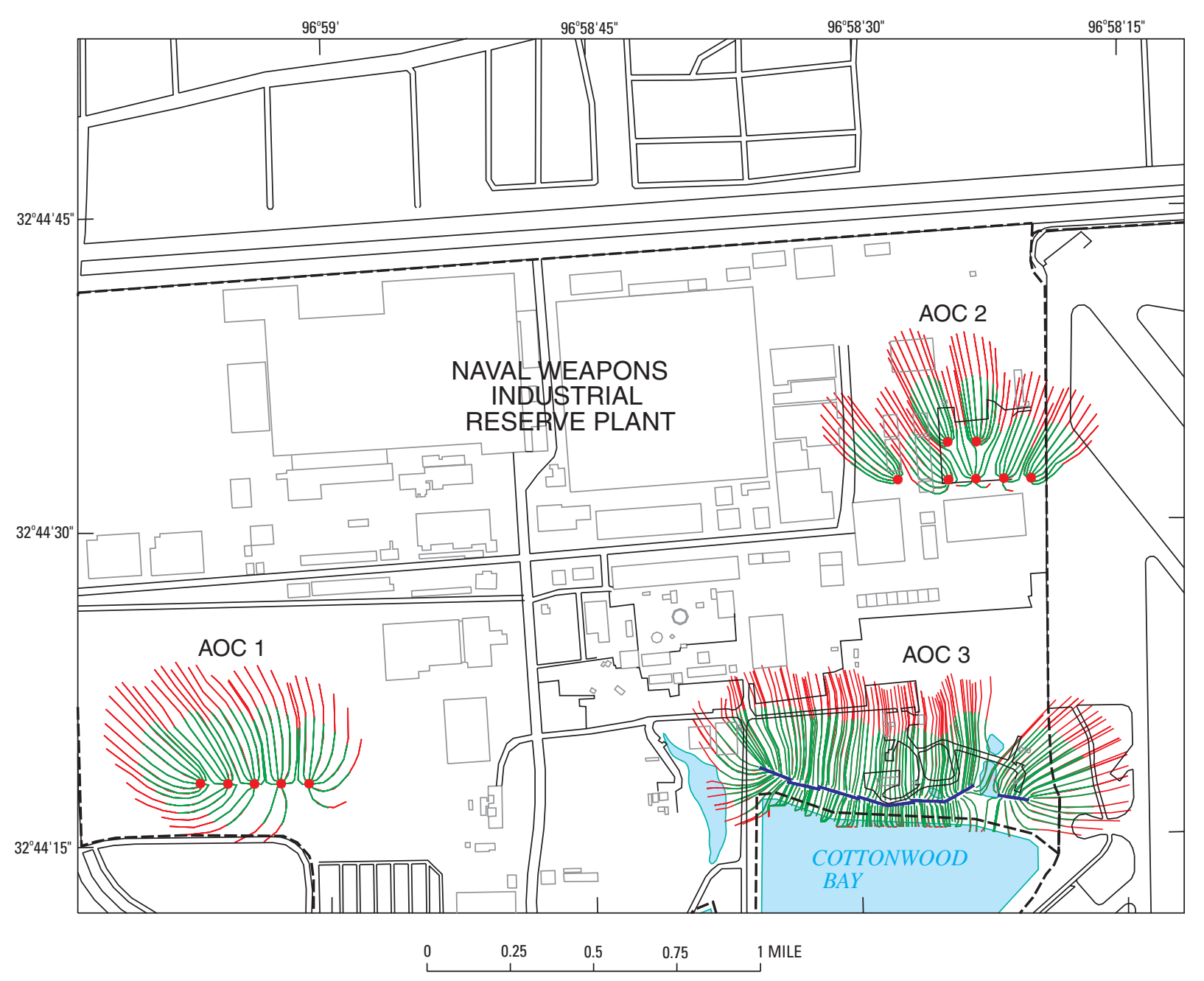

EXPLANATION

Flowline from 2.5-year remediation period

Flowline from 5-year remediation period

Trench

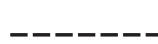

Boundary of Naval Weapons Industrial Reserve Plant

Well

Figure 27. Simulated distribution of backward particle-tracking flowlines depicting capture zones in the alluvial aquifer, resulting from 2.5- and 5-year remediation periods at Areas of Concern (AOC) 1, 2, and 3.

location of the trench, toward Cottonwood Bay. Figures 29 and 30 depict the effects of the trench, alone; the effect of remediation at AOC 1 or AOC 2 is not included. Figure 29 shows the rates at which water removed through the trench, on a segment-by-segment basis, without regard to direction (or side of trench) from which the ground water is intercepted. Figure 30 provides a segment-by-segment account of only the water draining northward into the trench from the Cottonwood Bay side of the trench.
The data in figures 28-30 indicate that, as of December 31, 1998, the trench at AOC 3 was intercepting about $827 \mathrm{ft}^{3} / \mathrm{d}$ of ground water that-without the trench - would have discharged into Cottonwood Bay. During the course of preventing about $827 \mathrm{ft}^{3} / \mathrm{d}$ of water from discharging into the bay (fig. 28), the trench is simulated to have removed about $3,221 \mathrm{ft}^{3} / \mathrm{d}$ of water from the aquifer (fig. 29), with about $934 \mathrm{ft}^{3} / \mathrm{d}$ (29 percent) of this water coming from the south (Cottonwood Bay) side of the trench (fig. 30). 


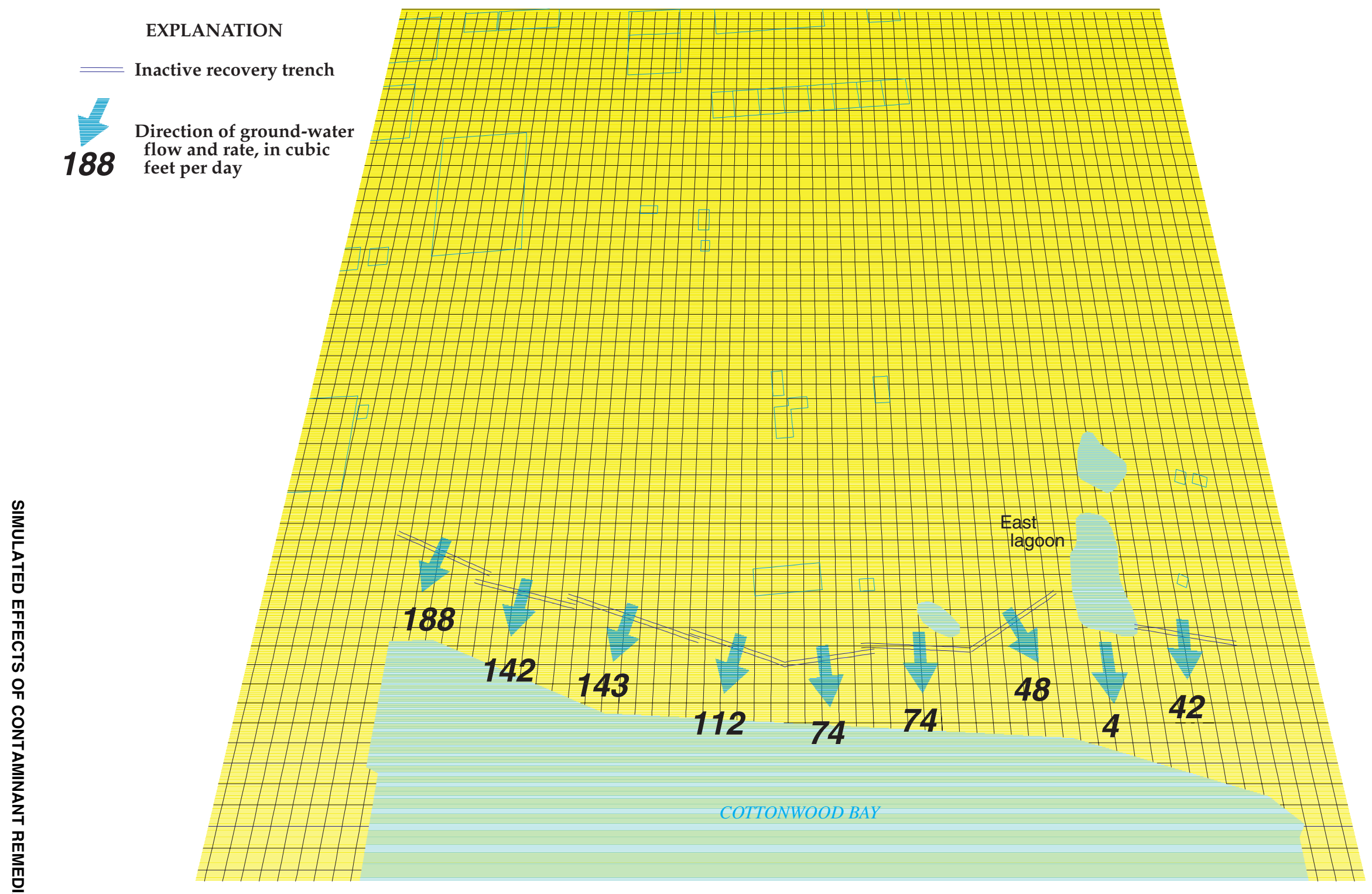

Figure 28. Simulated rates and directions of ground-water flow, as of December 31, 1998, between northern shoreline of Cottonwood Bay and $\omega$ trench at Area of Concern 3, assuming inactive recovery trench. 


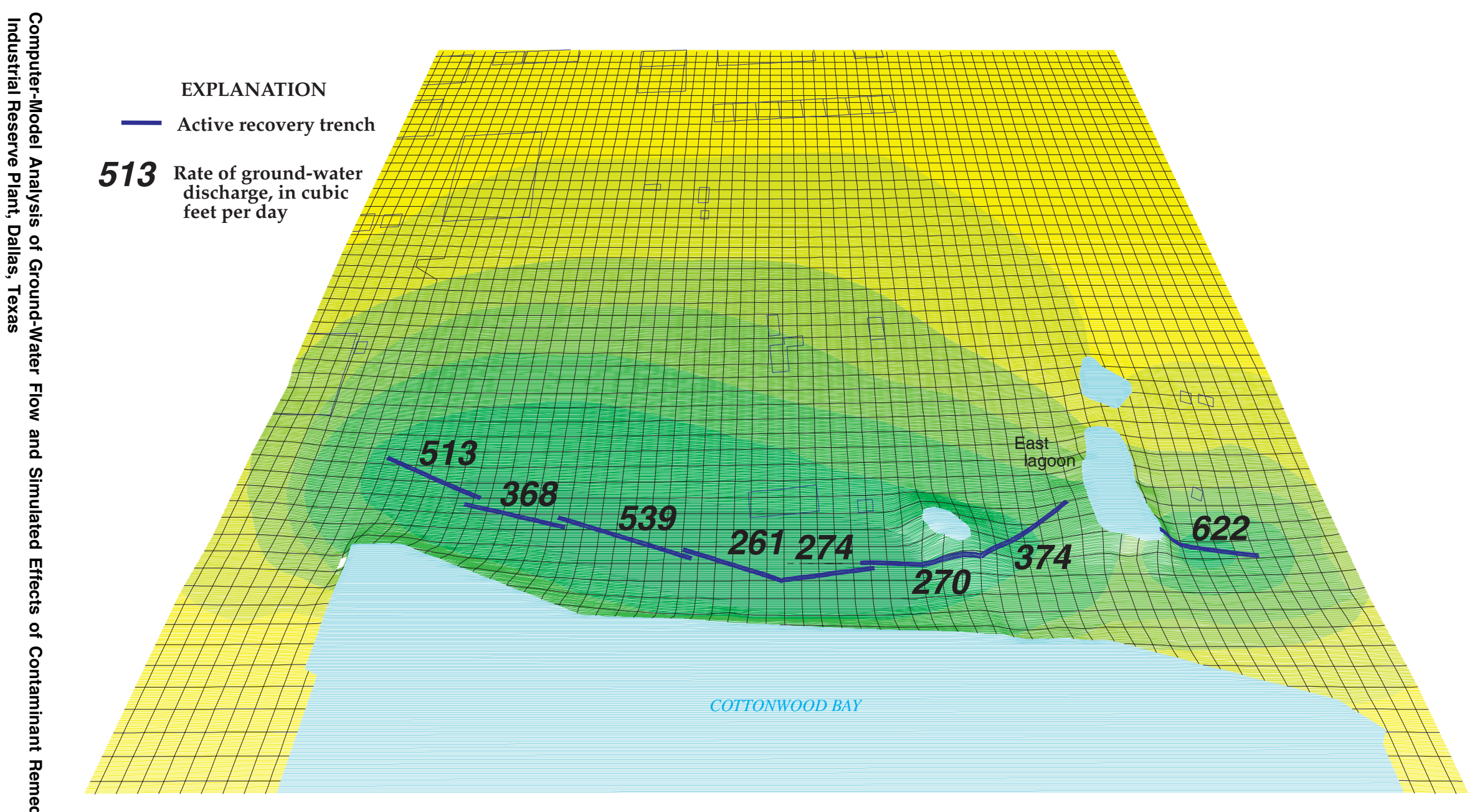

Figure 29. Simulated rates of ground-water discharge, as of December 31, 1998, to recovery trench at Area of Concern 3. 


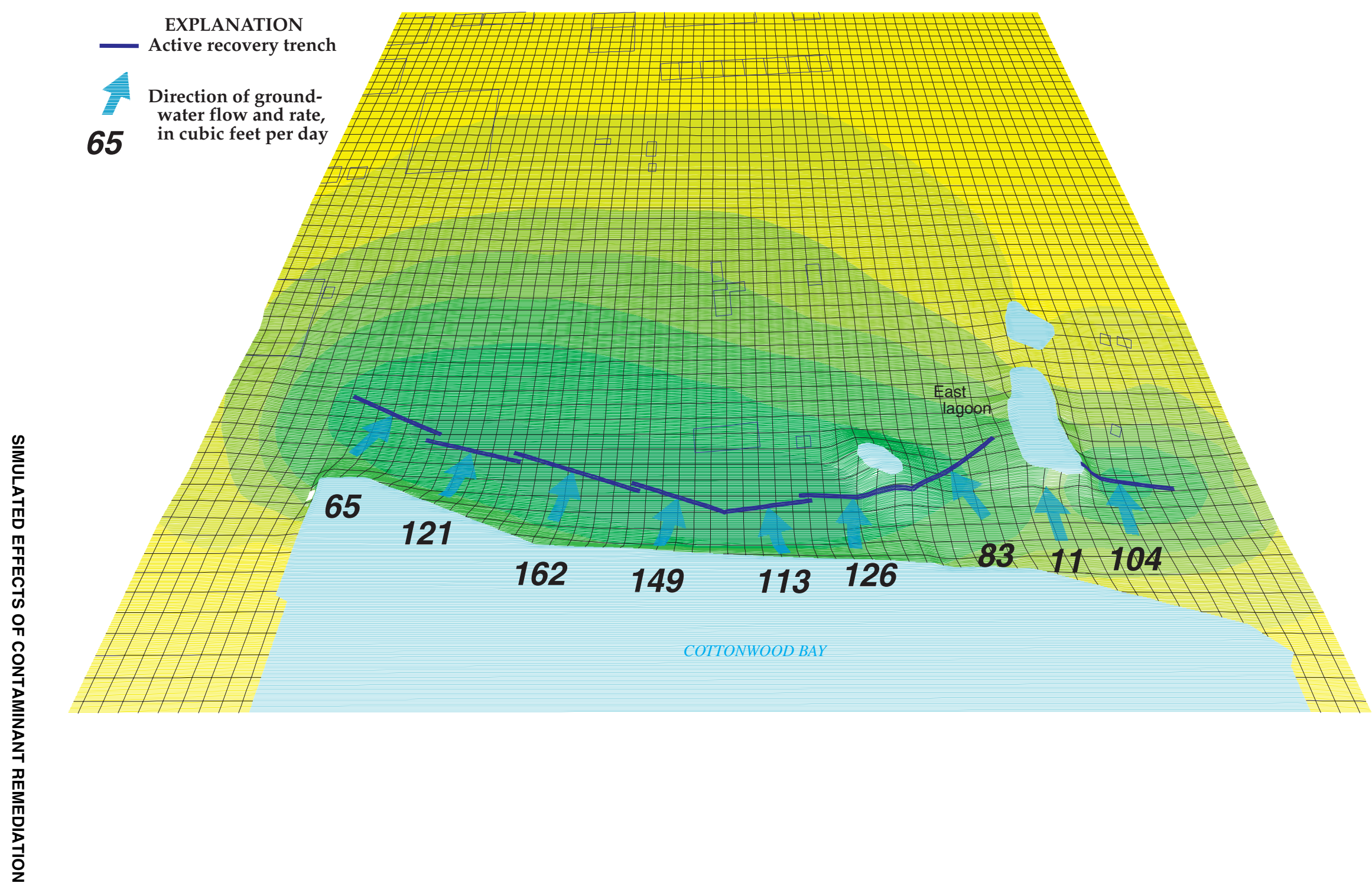

Figure 30. Simulated rates and directions of ground-water flow, as of December 31, 1998, between northern shoreline of Cottonwood Bay and $\pm \quad$ recovery trench at Area of Concern 3. 


\section{SUMMARY}

While conducting a RFI study of the NWIRP facility near Grand Prairie, Texas, the Department of the Navy (SOUTHDIV) has found TCE, DCE, VC, as well as chromium, lead, and other metals in the underlying shallow alluvial aquifer. Sediments in on-site drainage lagoons contain SVOCs, metals, pesticides and PCBs, and VOCs. These findings and the possibility of on-site or off-site migration of contaminants prompted a series of studies by the USGS to supplement the results of the RFI.

The USGS developed a digital computer model of the ground-water-flow system to: (1) define the hydraulic properties of the alluvial aquifer; (2) quantify the major components of recharge and discharge; (3) delineate preferential routes of ground-water flow; and (4) simulate the effects of recent as well as potential, future remediation activity. The MODFLOW computer code was used to simulate steady-state and transient conditions of ground water within a single model layer. Subsequently, the MODPATH code was used to delineate contaminant "capture zones" resulting from remediation systems operating since about July 1996. The calibrated USGS model provides the numerical framework for solute-transport modeling, if and when needed.

The model is linked to an ARC-INFO database with a finite-difference grid comprising 180 and 212 variably dimensioned rows and columns, respectively. The smallest cells, measuring $25 \mathrm{ft}$ to a side, are positioned over NWIRP, the principal area of interest. Noflow cells around the periphery of the model area surround 35,192 actively simulated cells. No-flow cells along the northern margins of the model approximate the hydraulic effects of a ground-water divide. Specified-head cells correspond to the stage of Mountain Creek Lake, as well as the western margin of the Mountain Creek swale.

The shallow alluvial aquifer is within fluvial terrace deposits of Pleistocene age, which unconformably overlie the relatively impermeable Eagle Ford Shale of Late Cretaceous age. The top of the Eagle Ford Shale is assumed to be the effective lower limit of ground-water circulation and chemical contamination. Although some fine-grained parts of the alluvial aquifer appear to be hydraulically separated over the course of short-term aquifer tests, most of the semiconfined-to-unconfined aquifer is connected circuitously through randomly distributed lenses of coarser grained sediments.
Saturated thicknesses range from less than $10 \mathrm{ft}$ around the eastern and western margins of the study area to nearly $60 \mathrm{ft}$ near the NWIRP midsection. The greatest thicknesses result from an erosional (now buried) channel that, from the northern part of NAS, trends generally southwestward and southward near the NWIRP midsection.

Ground-water altitudes range from about $495 \mathrm{ft}$ above sea level below a topographic ridge in the northwestern part of the study area to about $440 \mathrm{ft}$ near the Mountain Creek swale, on the east. Ground-water gradients, which slope mainly from northwest to southeast, steepen from less than $5 \mathrm{ft} / \mathrm{mi}$ near the groundwater divide to about 12 to $15 \mathrm{ft} / \mathrm{mi}$ near Cottonwood Bay. Upward gradients near the west and east lagoons and along the shorelines of Cottonwood Bay and Mountain Creek Lake indicate diffuse upward discharge to these low-lying surface-water bodies.

The source of most ground water in the alluvial aquifer is infiltrated precipitation, which mostly enters around the northern limits of the NWIRP/NAS compound. Simulated infiltration rates, ranging from 0 to $2.5 \mathrm{in} / \mathrm{yr}$, are distributed areally on the basis of ground cover. Most ground water discharges to downgradient drains, including Cottonwood Creek, Cottonwood Bay, Mountain Creek Lake, the west and east lagoons, and the Mountain Creek swale. A relatively small amount of ground water is lost through evapotranspiration.

The calibrated steady-state model reproduces long-term average water levels to within +5.1 or $-3.5 \mathrm{ft}$ of those observed. The standard error of the estimate is $1.07 \mathrm{ft}$, with a mean residual of $0.02 \mathrm{ft}$. Calibrated values of hydraulic conductivity range from 0.75 to $7.5 \mathrm{ft} / \mathrm{d}$ and average about $4 \mathrm{ft} / \mathrm{d}$. The calibrated specific-yield values range from 0.005 to 0.15 , and average about 0.08 . Drain conductance values range from 5.0 to $250 \mathrm{ft}^{2} / \mathrm{d}$.

The model is most sensitive to variations in the input rates of infiltration and input values of hydraulic conductivity. Maximum water-level changes of nearly $6 \mathrm{ft}$ (in opposite directions) are achieved by imposing 25-percent decreases in the calibrated values of either infiltration or hydraulic conductivity. Likewise, maximum water-level changes of between about 4 and $5 \mathrm{ft}$ result from increasing the calibrated values of either infiltration or hydraulic conductivity by 25 percent. The overall results of sensitivity testing indicate that the capability of the model to simulate actual conditions deteriorates as departures from the calibrated rates of 
infiltration and values of hydraulic conductivity and specific yield increase.

The simulated long-term average infiltration to the alluvial aquifer equals $15,910 \mathrm{ft}^{3} / \mathrm{d}$. The simulated discharge to Cottonwood Bay $\left(5,615 \mathrm{ft}^{3} / \mathrm{d}\right)$ is more than twice as much as any other component of discharge, and it exceeds the total outflow through all off-site creeks and both drainage lagoons $\left(4,725 \mathrm{ft}^{3} / \mathrm{d}\right)$, in addition to exceeding the combined discharge to Mountain Creek Lake, the Mountain Creek swale, and evapotranspiration $\left(5,570 \mathrm{ft}^{3} / \mathrm{d}\right)$.

Using monthly stress periods to update infiltration rates and pool levels, the calibrated transient model was run with different combinations of remediation activity in order to delineate: (1) capture zones resulting from well withdrawals and discharge to a downgradient recovery trench; (2) differences between pre- and post-remediation water levels and water budgets; and (3) distributions (rates and flowlines) of water withdrawn through the trench.

Computer simulation indicates that, as of December 31,1998 , the remediation systems at NWIRP were removing a total of $7,375 \mathrm{ft}^{3} / \mathrm{d}$ of water from the alluvial aquifer. The fraction coming directly from aquifer storage is simulated to have been $3,050 \mathrm{ft}^{3} / \mathrm{d}$. Compared to pre-remediation conditions, an additional $1,325 \mathrm{ft}^{3} / \mathrm{d}$ was being induced into the aquifer from Cottonwood Bay, in addition to $1,800 \mathrm{ft}^{3} / \mathrm{d}$ of ground water that (relative to pre-remediation conditions) was no longer discharging into the bay. An additional 1,200 $\mathrm{ft}^{3} / \mathrm{d}$ of water resulted from less discharge to the west lagoon, east lagoon, Mountain Creek Lake, and Mountain Creek swale, compared to pre-remediation conditions.

Particle-tracking analyses, assuming an aquifer porosity of 0.15 , were used to delineate capture zones resulting from 2.5- and 5-year periods of remediation activity at AOCs 1,2 , and 3 . The resulting flowlines indicate three such zones, or areas from which ground water is simulated to have been removed during July 1996-December 1998, as well as extended areas from which ground water would be removed during the next 2.5 years (January 1999-June 2001).

Simulation with the calibrated USGS model indicates that, as of December 31, 1998, the recovery trench was intercepting about $827 \mathrm{ft}^{3} / \mathrm{d}$ of ground water that - without the trench-would have discharged into Cottonwood Bay. Simulation indicates that, as of December 31, 1998, the recovery trench was removing about $3,221 \mathrm{ft}^{3} / \mathrm{d}$ of water from the aquifer, with about
$934 \mathrm{ft}^{3} / \mathrm{d}$ (29 percent) of this water coming from the south (Cottonwood Bay) side of the trench.

\section{REFERENCES CITED}

Alley, W.A., 1993, Regional ground-water quality: New York, N.Y., Van Nostrand Reinhold, 634 p.

Anaya, Roberto, Braun, C.L., and Kuniansky, E.L., 2000, Use of borehole geophysical logs for improved site characterization at Naval Weapons Industrial Reserve Plant, Dallas, Texas: U.S. Geological Survey Water-Resources Investigations Report 00-4150, $10 \mathrm{p}$.

Braun, C.L., Anaya, Roberto, and Kuniansky, E.L., 2000, Borehole geophysical logs at Naval Weapons Industrial Reserve Plant, Dallas, Texas: U.S. Geological Survey Open-File Report 00-076, 232 p.

Dallas Geological Society, 1965, The geology of Dallas County-A symposium on surface and subsurface geology, gravity, physiography, underground water supply, economic geology and engineering geology of Dallas County: Dallas Geological Society.

EnSafe/Allen \& Hoshall, 1994, Comprehensive long-term environmental action-Navy stabilization work plan; Revision I: Memphis, Tenn., EnSafe/Allen \&Hoshall, $83 \mathrm{p}$.

1996, Draft RCRA, facility investigation report, Naval Weapons Industrial Reserve Plant, Dallas, Texas_-Volume I: Memphis, Tenn., EnSafe/Allen \& Hoshall.

1997, Final stabilization performance evaluation report-Report \#1, Naval Weapons Industrial Reserve Plant, Dallas, Texas: Memphis, Tenn., EnSafe/Allen \& Hoshall.

1998, Draft stabilization performance evaluation report-Report \#2, Naval Weapons Industrial Reserve Plant, Dallas, Texas: Memphis, Tenn., EnSafe/Allen \& Hoshall.

Freeze, R.A., and Cherry, J.A., 1979, Groundwater: Englewood Cliffs, N.J., Prentice-Hall, 604 p.

Harbaugh, A.W., and McDonald, M.G., 1996, User's documentation for MODFLOW-96, an update to the U.S. Geological Survey Modular Finite-Difference GroundWater Flow Model: U.S. Geological Survey Open-File Report 96-485, 56 p.

Jones, S.A, and Paillet, F.L., 1997, Integrity of production wells and confining unit at the Naval Weapons Industrial Reserve Plant, Dallas, Texas, 1995: U.S. Geological Survey Water-Resources Investigations Report 97-4047, $30 \mathrm{p}$.

Larkin, T.J., and Bomar, G.W., 1983, Climatic atlas of Texas: Texas Department of Water Resources. 
McDonald, M.G., and Harbaugh, A.W., 1988, A modular three-dimensional finite-difference ground-water flow model: U.S. Geological Survey Techniques of WaterResources Investigations, book 6, chap. A1 [variously paged].

Owenby, J.R., and Ezell, D.S., 1992, Climatography of the United States-Monthly station normals of temperature, precipitation, and heating and cooling degree days 1961-91: Asheville, N.C., National Climatic Data Center, no. 81,65 p.

Pollock, D.W., 1989, Documentation of computer programs to compute and display pathlines using results from the U.S. Geological Survey modular three-dimensional finite-difference ground-water flow model: U.S. Geological Survey Open-File Report 89-381, 188 p.
U.S. Department of Commerce, 2000, National Climatic Data Center: National Oceanic and Atmospheric Administration, accessed July 12, 2000, at URL

http://www.ncdc.noaa.gov/

U.S. Geological Survey, 1986, National water summary 1985-Hydrologic events and surface-water resources: U.S. Geological Survey Water-Supply Paper 2300, $506 \mathrm{p}$.

2000, USGS geographic data download: Accessed July 12,2000 , at URL

http://edcwww.cr.usgs.gov/doc/edchome/ndcdb/ ndcdb.html

University of Texas, Bureau of Economic Geology, 1987, Geologic atlas of Texas, Dallas sheet: Austin, Tex., scale 1:250,000. 
District Chief

U.S. Geological Survey

8027 Exchange Dr.

Austin, TX 78754-4733 